OECD Working Papers on Insurance and Private Pensions No. 19

\title{
Coverage of Funded Pension Plans
}

\section{Pablo Antolín}




\title{
\ęC
}

\section{COVERAGE OF FUNDED PENSION PLANS}

\author{
Pablo Antolin
}

July 2008

\section{OECD WORKING PAPER ON INSURANCE AND PRIVATE PENSIONS}

No. 19

Financial Affairs Division, Directorate for Financial and Enterprise Affairs

Organisation for Economic Co-operation and Development

2 Rue André Pascal, Paris 75116, France

www.oecd.org/daf/fin/wp 


\begin{abstract}
RÉSUMÉ
Coverage of funded pension plans

This paper presents comparable and standardised data on coverage in voluntary funded pension plans for several OECD countries using household survey data by age, income level, and labour market status for occupational and personal pension plans. The analysis suggests that coverage is unevenly distributed across individuals and there is therefore a need to increase it, at least among the young and the mid-to-low income. The paper ends assessing different policies to increase coverage.
\end{abstract}

JEL codes: G23, J32

Keywords: Pension funds, coverage, household survey data.

$* * * * *$

\title{
La couverture de fonds de pensions de capitalisation
}

Ce document présente des données comparables et standardisées sur la couverture des plans de retraite de retraite volontaires pour plusieurs pays de l'OCDE en utilisant des données d'enquêtes ménages par âge, niveau de revenu et type de contrat de travail pour des plans de retraite de retraite professionnels et personnels. L'analyse suggère que la couverture est inégalement distribuée selon les individus et que, par conséquent, il y a un besoin de l'augmenter, au moins parmi les jeunes et les moyen-bas revenus. Le papier se termine par l'évaluation des différentes politiques afin d'augmenter la couverture.

JEL codes: $\mathrm{G} 23, \mathrm{~J} 32$

Mots clés: Fonds de pensions de capitalisation, couverture des plans de pensions, données d'enquêtes ménages.

\section{Copyright OECD, 2008}

Applications for permission to reproduce or translate all, or part of, this material should be made to: Head of Publications Service, OECD, 2 rue André-Pascal, 75775 Paris Cédex 16, France. 


\title{
COVERAGE OF FUNDED PENSION PLANS
}

\author{
by Pablo Antolin ${ }^{1}$
}

\section{Introduction}

Retirement savings in many OECD countries include savings in funded pension plans. Moreover, in several OECD countries, voluntary funded pension plans are the main vehicles to save for retirement. Therefore, in order to have an appraisal of savings available for retirement, this paper provides a preliminary assessment of the coverage of funded pension plans, focusing on voluntary arrangements. ${ }^{2}$ In this regard, it first discusses the policy relevance of examining the coverage of funded pension plans. Secondly, it examines the data at hand to measure coverage. Thirdly, it assesses the coverage in selected OECD countries for several population sub-groups. It then discusses policy measures to increase coverage, in particular, in those population subgroups with low coverage.

The focus is on the number of people enrolled in funded pension plans as a share of the employed population, i.e. the coverage of funded pension plans. Section 2 discusses the policy relevance of examining this measure. A key recommendation from Maintaining Prosperity in an Ageing Society (OECD, 1998) was to diversify the sources of retirement income. ${ }^{3}$ In this regard, funded pension plans complement the benefits provided by PAYG-financed pensions. Thus, examining their coverage allows gauging this complementary role. Additionally, although mandatory or quasi-mandatory pension plans, ${ }^{4}$ whether PAYG-financed or funded, guarantee that a large share of employed people will be enrolled, recent pension reforms in some OECD countries will lead to a fall in benefits as a share of past wages from mandatory pension systems, making an analysis of enrolment in voluntary funded schemes even more relevant.

Section three of the paper looks at the data at hand to examine coverage and the challenges posed by that data. After examining administrative data from funded pension plans and data from household surveys on individuals, section four presents measures of coverage for eight OECD countries (Australia, Canada,

\footnotetext{
${ }^{1}$ The author is principal economist of the private pensions unit at the OECD. He would like to thank the Delegates to the OECD Working Party on Private Pensions, André Laboul and Juan Yermo for their comments on previous versions of this paper. The author would also like to acknowledge the partial financial assistance from the EC. This paper has been possible thanks to the invaluable contribution of Markus Olapade. The views expressed are the sole responsibility of the author and do not necessarily reflect those of the OECD or its member countries.

${ }^{2}$ Throughout, this paper distinguishes among pension plans according to whether they are funded or financed as payas-you-go. The latter is generally identified with social security and similar statutory programmes administered by the general government as they are traditionally PAYG-financed. Funded pension plans are usually privately managed, and established as either occupational or personal plans. Funded plans accumulate dedicated assets to cover the plan's liabilities. These assets are assigned by law or contract to the pension plan (OECD, 2005a).

${ }^{3}$ This paper focuses only on income from funded pension plans, an important component of wealth at retirement, but it does not address other major sources of retirement wealth such as housing.

${ }^{4}$ Pensions are quasi-mandatory when it is not compulsory for workers to participate, but most workers are covered, either via collective bargaining agreements, or via nation-wide pension plans involving automatic enrolment with an opt-out clause.
} 
Finland, Germany, Ireland, Norway, United Kingdom and the United States) and Chile by age and income levels for different voluntary funded pension plans (occupational and personal). ${ }^{5}$

The main value added of this paper is to present comparable and standardised data on coverage in voluntary funded pension plans for several OECD countries using household survey data - which avoids problems of double counting --, by age, income level and labour market status for occupational and personal pension plans. Producing this data from household surveys from different countries required inputting the raw data into software that allow both programming and statistical analysis (e.g. Stata), checking for inconsistencies and misreporting problems, selecting the relevant subsample, calculating income levels and linking this information with personal and labour market characteristics. Future work could make use of this data and suitable econometric techniques to explain the patterns regarding the coverage of voluntary funded pensions by age, income and labour market status uncovered in this paper.

The last section of the paper considers whether there is a need to increase coverage in voluntary funded pension plans and assesses policies to broaden coverage. It concludes that as coverage is unevenly distributed across individuals, there is a need to increase it, at least, among the young and the mid-to-low income groups. Additionally, the assessment of policies suggests that some type of soft-compulsion, for example, automatic enrolment may achieve the goal of increasing coverage among those population subgroups with low coverage maintaining at the same time individual choice through opt-out options. Yet, coverage can be partially increased without resorting to any type of compulsion by improving eligibility and incentives for enrolment, as well as by improving information disclosure and awareness about the need to save for retirement.

\section{The policy relevance of examining the coverage of funded pensions}

This paper measures coverage as the share of people employed that are enrolled or participate in pension plans. However, when pension plans are compulsory or quasi-compulsory, the coverage of pension plans in terms of enrolment loses its relevance as most people will be enrolled. Furthermore, looking at coverage as the amount of people participating or enrolled in pension plans gives only a partial picture of their retirement wealth. Contributions to these plans, the length of the contribution period, the rate of return on investments and the length of the pay-out period will determine the benefits paid at retirement, hence complementing this picture. In this context, and specially when dealing with mandatory arrangements, it is important to examine the amount of previous wages "replaced" by the benefits that pension plans pay (i.e. the replacement rate).

The policy relevance of examining the coverage of funded pension plans stems from the need to diversify the sources of income at retirement and from the replacement rate of PAYG-financed public pension plans. A key recommendation from Maintaining Prosperity in an Ageing Society (OECD, 1998) was to diversify the sources of income at retirement. For example, as funded pension plans seem less exposed than PAYG-funded pensions to the impact of ageing populations (Lindbeck and Pearson, 2003), diversifying the sources of income at retirement between both is recommended to face the impact of ageing. However, high replacement rates of PAYG-financed public pension plans can deter this diversification as people may have relatively enough retirement benefits. On the other hand, if replacement rates from PAYG-financed public pensions are low, ${ }^{6}$ people would need to have additional savings in

\footnotetext{
${ }^{5}$ It is compulsory for employers to contribute on behalf of their employees to funded pension plans in Australia, while it is voluntary for employees and the self-employed to contribute to these plans. This distinction will lead to interesting results below. In Chile, it is compulsory for employees to contribute to funded pension plans, while it is voluntary for the self-employed. Despite this, due to informality in the labour market, coverage is far from universal in Chile.

${ }^{6}$ It is quite subjective to assess a replacement rate as high or low. Many countries consider that a replacement of $60 \%$ of last wages is a reasonable threshold. The approach taken in this paper is to focus on the complementary role of pension benefits from voluntary funded pension plans: they complement pension benefits from PAYG-funded public pensions and mandatory funded pensions. Additionally, the appropriate replacement
} 
funded pension plans to complement their retirement income diversifying, therefore, the sources of income at retirement.

Examining PAYG-financed public pension plans shows that the benefits they provide fail to replace a large proportion of previous wages. ${ }^{7}$ Furthermore, the replacement of previous wages decreases with income. Pension benefits in PAYG-financed pensions for new employees replace around $47 \%$ of previous wages when considering individuals with average income (figure 1). This replacement varies from more than 70 percent in Austria, Luxemburg, Greece, Spain and Turkey to less than 30\% in Australia, Iceland, Mexico, Poland, and the Slovak Republic. However, when considering low income individuals (i.e. those with wages half of average wages), benefits from PAYG-financed pensions replace a higher share of past wages, around $63 \%$ on average for the OECD, varying from more than 70 percent in Austria, Canada, Czech Republic, Denmark, Finland, Greece, Korea, Luxemburg, New Zealand, Portugal, Spain, and Turkey; to less than 30\% in Mexico, Poland and the Slovak Republic. On the other hand, when considering high income individuals (i.e. those with wages at twice the average wage) benefits from PAYG-financed pension replace on average around 36 percent of past wages, varying from less than $30 \%$ in Australia, Belgium, Canada, Czech Republic, Denmark, Iceland, Mexico, the Netherlands, New Zealand, Poland, Slovak Republic, Sweden, and the United Kingdom, to more than $80 \%$ for only two countries (Greece and Luxemburg).

rate from PAYG-financed public pension plans cannot be assessed in isolation from issues of financial sustainability of public finances and from the amount that people contribute to the plan.

${ }^{7}$ This replacement rates refer to an individual with a full contribution record. 
Figure 1. Gross replacement rates in PAYG-financed pension plans
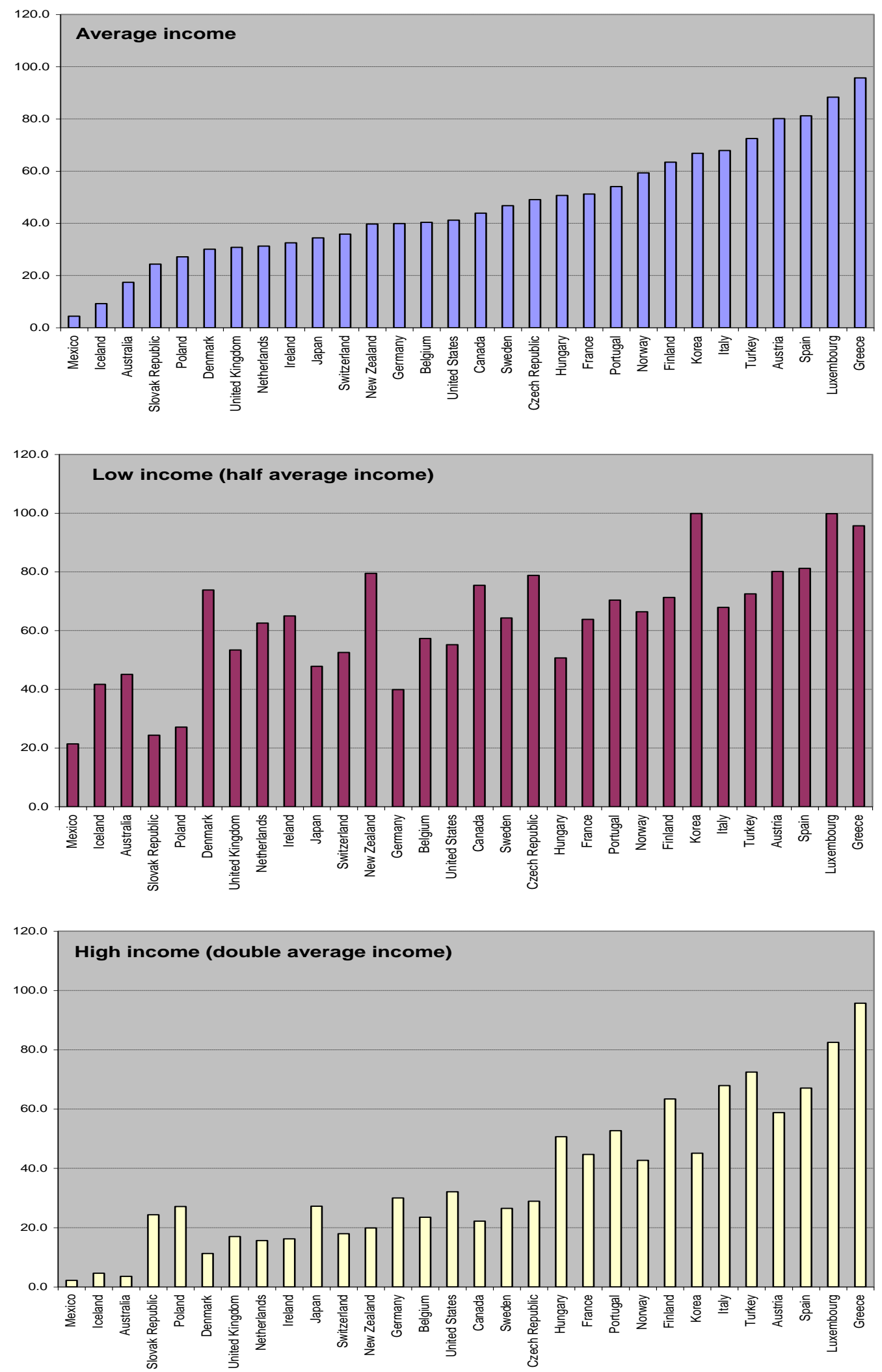

Source: Pensions at a Glance (OECD), 2007.

Note: Gross replacement rates for an individual entering the pension system in each country at age 25 . 
Consequently, people may need to have additional saving in funded pension plans to complement their benefits from PAYG-financed public pension plans. However, examining whether people have additional savings in these plans requires distinguishing between mandatory or quasi-mandatory ${ }^{8}(e . g$. the Netherlands) and voluntary (e.g. the United States) funded pension plans. In mandatory or quasimandatory funded pension plans most workers will be enrolled. However, enrolment does not necessary entail high replacement rates. Replacement rates for given wages will depend on the contribution rate, the number of periods contributed, and the return rate on investments, as well as the length of the pay-out period. ${ }^{9}$ On the other hand, when considering voluntary pension plans, assessing coverage begins by examining the share of employed people enrolled in those plans.

Looking into the amount of previous wages replaced by mandatory pension plans, both PAYGfinanced or funded, suggests that there may be a need for additional retirement savings in voluntary funded pension plans to complement and diversify retirement income. Figure 2 shows the coverage or replacement of previous wages by pension benefits from these plans. ${ }^{10}$ These replacement rates are above $40 \%$ in Denmark (for average and high income individuals), Iceland (for all income levels), the Netherlands (for average and high income individuals) and for Sweden (for high income individuals). Combining PAYGfinanced and funded mandatory and quasi-mandatory pension plans, before and after tax (figures 3 and 4), shows that the replacement of previous wages by mandatory pension plans in OECD countries fails to replace a large share of previous wages in many OECD countries.

\footnotetext{
${ }^{8}$ See footnote 4 for a definition.

${ }^{9}$ In this regard, in countries with high levels of labour market informality (e.g. Chile, Mexico) high coverage may not translate into large contributions and benefit accrual records. Additionally, mandatory plans with different contribution rates will provide different benefits. In the case of Chile, the data examined below shows that the coverage rate is as a result far from universal.

${ }^{10}$ As of 2006, only 10 countries had mandatory funded pension plans. New Zealand (Kiwisaver) and Norway have introduced mandatory funded schemes in 2007. Therefore, their replacement rates only include PAYGfinanced pensions.
} 
Figure 2. Gross replacement rates in mandatory funded pension plans
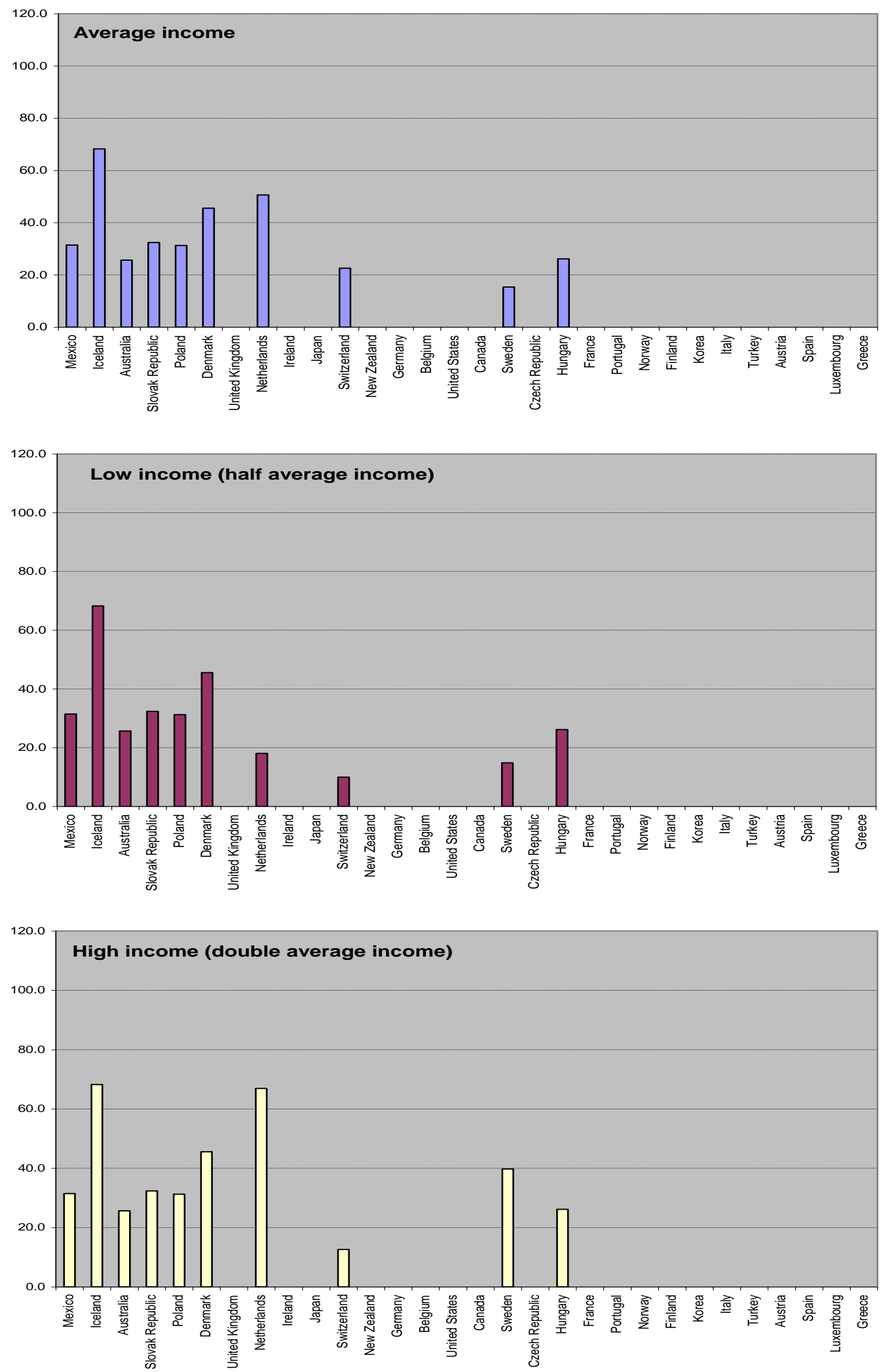

Source: Pensions at a Glance (OECD), 2007.

Note: Gross replacement rates for an individual entering the pension system in each country at age 25. 
Figure 3. Gross replacement rates in mandatory pension plans (PAYG-financed and funded)
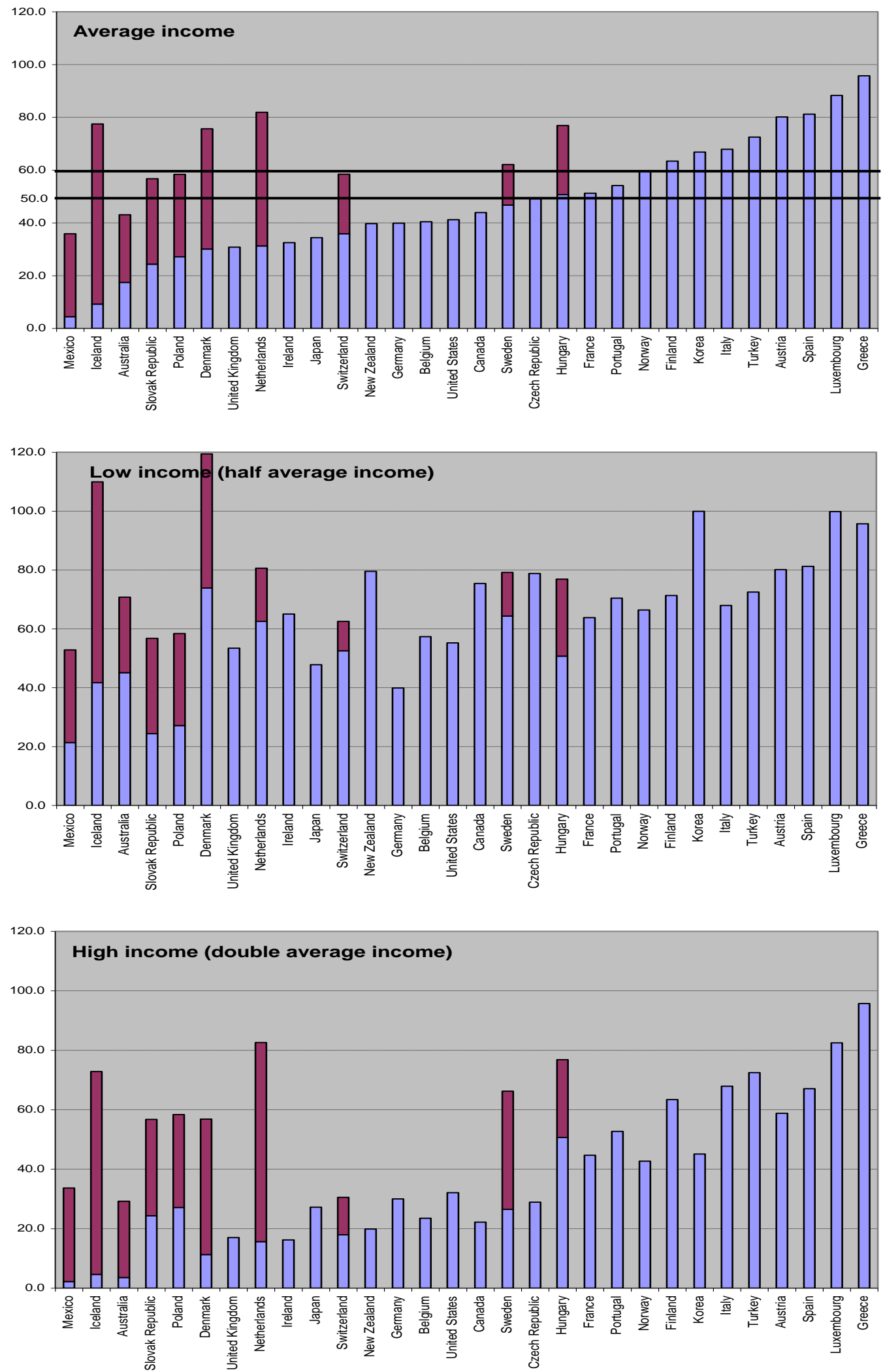

Source: Pensions at a Glance (OECD), 2007.

Note: Gross replacement rates for an individual entering the pension system in each country at age 25 . 
Figure 4. Net replacement rates in mandatory pension plans
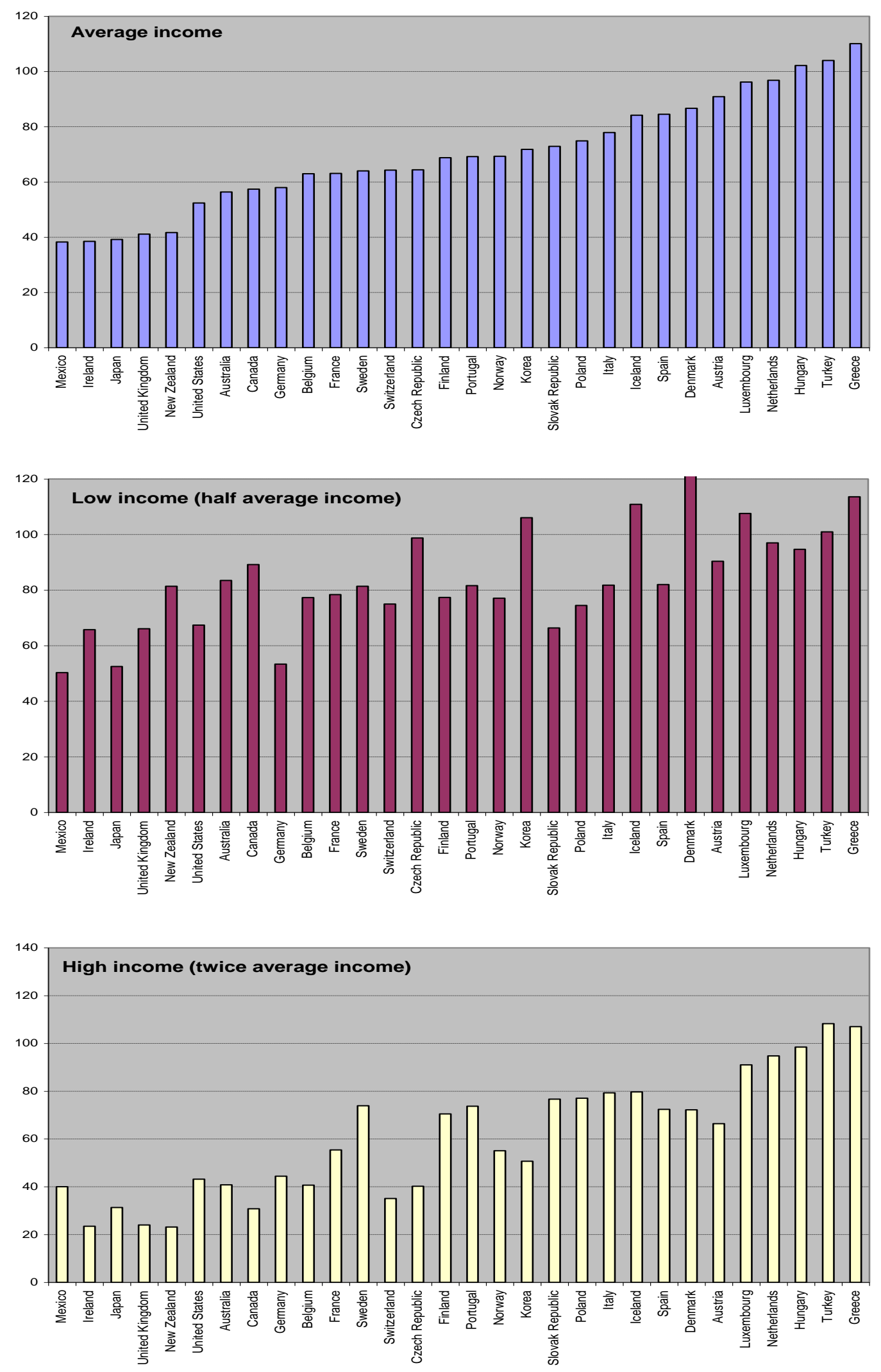

Source: Pensions at a Glance (OECD), 2007.

Note: Gross replacement rates for an individual entering the pension system in each country at age 25. 
Consequently, the main policy issue addressed in the rest of the paper is to assess the coverage or enrolment in voluntary funded pension plans. In countries where mandatory PAYG-funded pension plans provide low replacement rates and funded private pension plans are voluntary (e.g. the United States, the United Kingdom), the coverage of voluntary funded private pension plans becomes a key political issue because this is the first measure to gauge whether people will have enough income for retirement. On the other hand, countries where mandatory or quasi-mandatory pension plans, either PAYG-financed (e.g. Greece, Italy, Sweden, Spain) or combined PAYG-financed and funded (e.g. the Netherlands), provide a high replacement rate, the coverage of voluntary funded pension plans becomes important either because reforms to public systems will reduce benefits or because replacement rates are low for certain income levels or population groups (table 1). For example, as a result of recent reforms, replacement rates in mandatory pension plans may be lower for young individuals than for older workers, coupled this with low coverage of voluntary pension plans, and future retirees may face financial problems. Finally, apart from examining the coverage of voluntary funded pensions in terms of people enrolled or participating in them, it is also important to examine the share of previous income replaced by the benefits from voluntary funded pensions, comparing it to that of mandatory PAYG-financed and funded pensions. This will be part of future work.

Table 1. Type of Pension Plans in OECD countries

\begin{tabular}{|c|c|c|c|c|c|c|c|c|}
\hline \multirow[b]{3}{*}{ Countries } & \multirow{3}{*}{$\begin{array}{c}\begin{array}{c}\text { PAYG- } \\
\text { financed } \\
\text { pensions }\end{array} \\
\begin{array}{c}\text { Gross } \\
\text { replacement } \\
\text { rate }^{1}\end{array}\end{array}$} & \multicolumn{5}{|c|}{ Funded pension plans } & \multirow{2}{*}{\multicolumn{2}{|c|}{$\begin{array}{l}\text { Mandatory pension } \\
\text { plans }\end{array}$}} \\
\hline & & \multicolumn{3}{|c|}{ Mandatory or quasi-mandatory } & \multicolumn{2}{|c|}{ Voluntary } & & \\
\hline & & Occupational & Personal & $\begin{array}{c}\text { replacement } \\
\text { rate }^{1,2}\end{array}$ & Occupational & Personal & Gross & Net \\
\hline Australia & 17.4 & $Y$ & $\mathrm{Y}$ & 25.7 & & $Y$ & 43.1 & 56.4 \\
\hline Austria & 80.1 & & & & $\mathrm{Y}$ & Y & 80.1 & 90.9 \\
\hline Belgium & 40.4 & & & & $\mathrm{Y}$ & $\mathrm{Y}$ & 40.4 & 63.0 \\
\hline Canada & 43.9 & & & & $\mathrm{Y}$ & $\mathrm{Y}$ & 43.9 & 57.4 \\
\hline Czech Republic & 49.1 & & & & & Y & 49.1 & 64.4 \\
\hline Denmark & 30.2 & Y & Y & 45.6 & $\mathrm{Y}$ & $\mathrm{Y}$ & 75.8 & 86.7 \\
\hline Finland & 63.4 & $\mathrm{Y}$ & & & $\mathrm{Y}$ & $\mathrm{Y}$ & 63.4 & 68.8 \\
\hline France & 51.2 & & & & $\mathrm{Y}$ & Y & 51.2 & 63.1 \\
\hline Germany & 39.9 & & & & $\mathrm{Y}$ & $\mathrm{Y}$ & 39.9 & 58.0 \\
\hline Greece & 95.7 & & & & $Y$ & Y & 95.7 & 110.1 \\
\hline Hungary & 50.7 & Y & $Y$ & 26.2 & $\mathrm{Y}$ & $Y$ & 76.9 & 102.2 \\
\hline Iceland & 9.2 & $Y$ & & 68.3 & & $Y$ & 77.5 & 84.2 \\
\hline Ireland & 32.5 & & & & $\mathrm{Y}$ & $Y$ & 32.5 & 38.5 \\
\hline Italy & 67.9 & $Y$ & & & $Y$ & $Y$ & 67.9 & 77.9 \\
\hline Japan & 34.4 & & & & Y & Y & 34.4 & 39.2 \\
\hline Korea & 66.8 & & & & $Y$ & $Y$ & 66.8 & 71.8 \\
\hline Luxembourg & 88.3 & & & & $\mathrm{Y}$ & $Y$ & 88.3 & 96.2 \\
\hline Mexico & 4.4 & & Y & 31.4 & & $\mathrm{Y}$ & 35.8 & 38.3 \\
\hline Netherlands & 31.3 & $Y$ & & 50.6 & $Y$ & Y & 81.9 & 96.8 \\
\hline New Zealand & 39.7 & $Y$ & $Y$ & & $\mathrm{Y}$ & $Y$ & 39.7 & 41.7 \\
\hline Norway & 59.3 & $Y$ & & & $Y$ & $\mathrm{Y}$ & 59.3 & 69.3 \\
\hline Poland & 29.9 & & $Y$ & 31.3 & $Y$ & $\mathrm{Y}$ & 61.2 & 74.9 \\
\hline Portugal & 54.1 & & & & $Y$ & $Y$ & 54.1 & 69.2 \\
\hline Slovak Republic & 24.3 & & $Y$ & 32.4 & $Y$ & Y & 56.7 & 72.9 \\
\hline Spain & 81.2 & & & & $\mathrm{Y}$ & $Y$ & 81.2 & 84.5 \\
\hline Sweden & 46.7 & $Y$ & $Y$ & 15.4 & $Y$ & Y & 62.1 & 64.0 \\
\hline Switzerland & 35.8 & $Y$ & & 22.6 & & $\mathrm{Y}$ & 58.4 & 64.3 \\
\hline Turkey & 72.5 & & & & $Y$ & Y & 72.5 & 104.0 \\
\hline United Kingdom & 30.8 & & & & $Y$ & $Y$ & 30.8 & 41.1 \\
\hline United States & 41.2 & & & & $Y$ & $Y$ & 41.2 & 52.4 \\
\hline OECD average & 58.7 & 10 out of 30 & 8 out of 30 & & 26 out of 30 & all & 58.7 & 70.1 \\
\hline
\end{tabular}

Source: OECD Pensions at a Glance (2007) for replacement rates and OECD Private Pension Statistics.

Notes:

(1) These rates correspond to an average income individuals entering the labour force at 25 and working until the official age of retirement. In this regard, they can be understood as a potential maximum.

(2) Replacement rates for mandatory funded pension plans in Italy (TFR), New Zealand (Kiwisaver) and Norway are not available yet, as those plans have been introduced in 2007. Replacement rates for PAYG-funded pension plans in Finland include the funded part of their system ( $1 / 3$ of contributions is funded). 


\section{The challenges posed by the data available to estimate enrolment in funded pension plans}

This section examines the data available to calculate coverage in funded pension plans. First, this section examines the problems that exist with the available data when producing comparable and meaningful data on coverage, and, secondly, it discusses the kind of data needed to measure coverage. It concludes that household survey data are best suited for calculating coverage in funded pension plans. Nevertheless, they also have some problems that complicate their use. Additionally, extracting data from household surveys is a cumbersome task, not least because the need to clean the data from inconsistencies and misreporting, and select the appropriate subsample.

There are two broad types of data sources to assess the enrolment or coverage of funded pension plans. First, there is administrative data from pension plans that provide the number of members in each plan, assets under management and benefits paid to those already retired. ${ }^{11}$ Secondly, there are household surveys where individual are interviewed and asked about whether they are enrolled, have assets, contribute to or receive pension benefits from funded pension plans.

Unfortunately, administrative data suffers from a problem of double counting. This type of data provides a misleading picture of the number of people enrolled in pension plans as individuals can be enrolled in more than one pension plan at the same time. For example, an individual can be at the same time enrolled in an occupational pension plan (e.g. 401(k) in the United States) and in a personal pension plan (e.g. IRA in the United States). Additionally, double counting can result from deferred members in occupational plans.

Household survey data, on the other hand, can help in determining the number of people enrolled in funded pension plans. ${ }^{12}$ Because in household surveys people are interviewed directly, it is, in principle, possible to determine both whether they are enrolled in funded pension plans and in how many of them. However, the questions posed to individuals in household surveys are not always suitable to calculate the number of employed people who are enrolled in funded pension plans.

Unfortunately, only some of the variables related to funded pension plans in household surveys are appropriate to calculate pension coverage accurately. Variables indicating whether individuals receive income from funded pensions fail to give a complete picture of private pension coverage because only people who are already retired get benefits. Therefore, all the people who are enrolled in funded pension plans but are not retired will not be identified. On the other hand, variables that indicate whether individuals are members or are enrolled in funded pension plans, or are contributing to these plans, or have assets in funded pension plans allow calculating the coverage of funded pension accurately.

Additionally, the design of several surveys focused specifically on retirement issues prevents using them to estimate the coverage or enrolment in funded pension plans. For example, the University of Michigan Health and Retirement Study (HRS) widely used to examine retirement issues in the United States (e.g. Gale and Phillips, 2006), the English Longitudinal Study of Ageing (ELSA), and the Survey of Health, Ageing and Retirement in Europe (SHARE) provide a wealth of information about individuals and their retirement savings and benefits. Alas, they only survey individuals aged 50 or older, making it impossible to measure coverage of the working age population. Nevertheless, these household surveys will be useful for future studies assessing replacement rates on voluntary funded pension plans. Additionally, the available waves of the European Community Household Panel (ECHP) lack appropriate variables to

${ }^{11}$ Regarding pension benefits paid, many pension funds only provide information on total pension benefits paid annually without separating lump-sum payments from benefits paid at regular intervals (e.g. annual payments).

12 The OECD has produced a review examining which of the main household surveys available in several OECD countries have relevant information to calculate coverage of funded pension plans (available on request). 
calculate pension coverage. ${ }^{13}$ Finally, a recent data set providing information on household wealth, the Luxemburg Wealth Study data set, contains information that allows calculating coverage for a few OECD countries. Unfortunately, the information is a bit out of data (e.g. you can get more up to date information on coverage going to the source data for countries like Canada and the United States).

Nevertheless, in what follows, this paper uses data from household surveys that allow estimating coverage. It examines the number of people enrolled in funded pension plans in several OECD countries where mandatory pension plans, including both PAYG-financed and funded, public and private, provide a relatively low replacement of previous wages, and people need therefore to rely on voluntary contributions to funded pension plans to complement their future retirement income (Table 1).

\section{Coverage or enrolment in voluntary funded pension plans in selected OECD countries}

This section presents the results of calculating the coverage of voluntary funded pension plans in eight OECD countries (Australia, Canada, Finland, Germany, Ireland, Norway, United Kingdom and the United States) and Chile by age, income levels, labour market status (full-time vs. part-time; employees vs. selfemployed) and for different pension plans (e.g. occupational and personal) using household survey data. These calculations have been produced by extracting, processing, checking and organising the information from household survey data from different countries, using software that allows programming and statistical analysis (Stata). As a result of selecting comparable samples, calculating standardised income levels, and linking this information with personal and labour market characteristics, these are comparable and standardised data on coverage in voluntary funded pension plans, which avoid problems of double counting.

The analysis of the data on coverage permits to reach several general conclusions. ${ }^{14}$ Firstly, coverage in occupational pension plans is larger than coverage in personal plans. Secondly, coverage shows a humpshaped relationship with age, peaking around age 45-54. Thirdly, coverage increases with income. Fourthly, full-time workers and employees are more likely to be enrolled in funded pensions than part-time workers and the self-employed, respectively. Fifthly, coverage rates for men are slightly higher than coverage rates for women in voluntary pension arrangements. Sixthly, the number of people enrolled in more than one funded pension plan is non-negligible.

The coverage in funded pension plans is well above $50 \%$ in most countries considered (table 2). In Canada, Ireland and the United Kingdom and the United States, where funded private pension plans are voluntary and the benefit coverage of public schemes is relatively low, the share of people who are members of funded pension plans is more than half of the employed population, around $60 \%$ for all these. In Germany, the share of those in employment having a life insurance or being enrolled in a funded private pension plan was almost $68 \%$ in $2002 .{ }^{15}$ When focusing on Riester pension plans, the coverage was already $9.4 \%$ in 2004, despite these plans being in place only since 2002. ${ }^{16}$ In Australia, where employers are obliged to contribute to pension funds, while employees and the self-employed are not, $85 \%$ of those in employment are enrolled in funded pension plans, but only $27 \%$ make personal voluntary contributions to

${ }^{13}$ It contains variables reporting income from private pensions plans. However, only people already retired are entitled to pension benefits. This is a shame because many of the individual countries household surveys used to compile the ECHP do include variables reported either participation or contributing to private funded pension plans.

${ }^{14}$ The annex presents a set of tables for each country showing coverage by age, income, labour market status and type of pension plans, occupational and personal, and distinguishing, whenever possible, between DB and DC plans.

${ }^{15}$ This is the last year in which the GSOEP provides this kind of information.

${ }^{16}$ The Riester funded pension plans where introduced in Germany in 2002. These are defined contribution personal plans that complement public pension benefits. Contributions to them entitled to a flat government subsidy or a tax deduction. 
those plans. In Finland and Norway, where PAYG-financed pensions provide a relative large replacement rate (figure 1), coverage in voluntary funded pension plans (personal plans) is relative low. Finally, in Chile, despite of its mandatory nature for employees, and due to informality (Vial and Melguizo, 2008; Rofman and Lucchetti, 2006), coverage is far from universal but on par with the coverage in Canada, Ireland, United Kingdom and the United States.

Table 2. People enrolled in voluntary funded pension plans, selected OECD countries

(Percentage of total employment)

Australia (2002) ${ }^{1}$
Australia (2002)
Canada $(2004)^{2}$
Chile $(2006)$
Finland (1998)
Germany $(2002 / 2004)^{4}$
Ireland (2005Q4)
Norway (2002)
United Kingdom (2004)
United States (2005)

\begin{tabular}{ccc} 
Total & $\begin{array}{c}\text { Occupational } \\
\text { plans }\end{array}$ & $\begin{array}{c}\text { Personal } \\
\text { plans }\end{array}$ \\
\hline 85.0 & 77.1 & 9.7 \\
26.7 & 18.8 & 9.7 \\
53.7 & 39.4 & \\
53.6 & & 53.6 \\
& & 7.3 \\
67.9 & 9.4 & \\
55.0 & 42.9 & 14.9 \\
& & 3.0 \\
59.1 & 47.1 & 18.9 \\
57.7 & 46.0 & 34.7
\end{tabular}

Source: OECD calculations using the Canadian Survey of Labour and Income Dynamics (SLID), the German Socio-Economic Panel (GSOEP), the Irish Quarterly National Household Survey (QNHS), the British Household Panel (BHPS), the United States Panel Study of Income Dynamics (PSID), and the Luxembourg Wealth Study dataset (LWS). The OECD would like to thank Mark Pearson for producing the data for Australia using the survey on Household, Income and Labour Dynamics in Australia (HILDA) and Gonzalo Reyes (Director of the Research Department of the Superintendence in Chile) for providing us with the Chilean data.

Notes:

(1) The first row includes all people enrolled in any superannuation fund either with only employer contributions (mandatory), both employer and personal contributions (mandatory and voluntary), or only personal (voluntary) contributions. The second row only includes people enrolled in any superannuation fund with personal (voluntary) contributions.

(2) The SLID provides information on individuals participating in registered pension plans (RPP) and group registered retirement saving plans (group RRSP) which are both employer-sponsored plans. The figure for total comes from the tax records and comprises all individuals contributing to RPP and registered retirement saving plans (RRSP). The later are individually sponsored plans.

(3) Data for Finland and Norway come from the new data set Luxembourg Wealth Study. The data refers to people with pension assets in private pension accounts (Norway) and in annuities and other deferred retirement products (Finland). See http://www.lisproject.org/ for reference.

(4) The total includes life insurance and pension plans for the year 2002, while the number on occupational plans is the Riester pensions as of 2004. Data for personal plans is not available. 
There are more people in employment enrolled in occupational plans than in personal plans (Table 2). In Australia, Ireland and the United Kingdom enrolment in occupational plans is more than double, while in Canada enrolment is higher in personal plans. ${ }^{17}$ In the United States, on the hand, the share of the employment population enrolled in personal pension plans is quite large and only around 10 percentage points below the enrolment rate in occupational plans. ${ }^{18}$

Coverage in voluntary funded pension plans shows a hump-shaped relationship with age, peaking around age 45-54 (figure 5). The share of those in employment enrolled in voluntary funded pension plans increases with age in all countries, reaching a peak at prime working ages, i.e. ages from 35 to 44 or 45 to 54 , depending of the country, and falling afterwards. However, young people are more likely to be enrolled in a Riester funded pension in Germany than older people, reflecting, most likely, their recent introduction. The fall in coverage rates at old working ages occurs in all countries except in Finland, Norway and the United States, and it could be linked to early retirement. In this regard, Norway and the United States have high effective average retirement ages relative to other OECD countries. Moreover, voluntary funded pension plans in the two Nordic countries are on top of generous public pensions.

\footnotetext{
${ }^{17}$ Enrolment in registered pension plans (RPP), which are occupational funded pension plans, is 10 percentage points higher than enrolment in registered retirements saving plans (RRSP), which are personal funded pension plans.

${ }^{18}$ The data for the United States allows splitting the coverage in occupational funded pensions into defined-benefit (DB) and defined-contribution (DC) funded plans (Annex). Despite, the large shift to DC plans in recent years, there still remains more people enrolled in occupational DB plans than in occupational DC plans, around four percentages point more.
} 
Figure 5. Coverage in voluntary funded pension plans according to age

(\% of total employment)
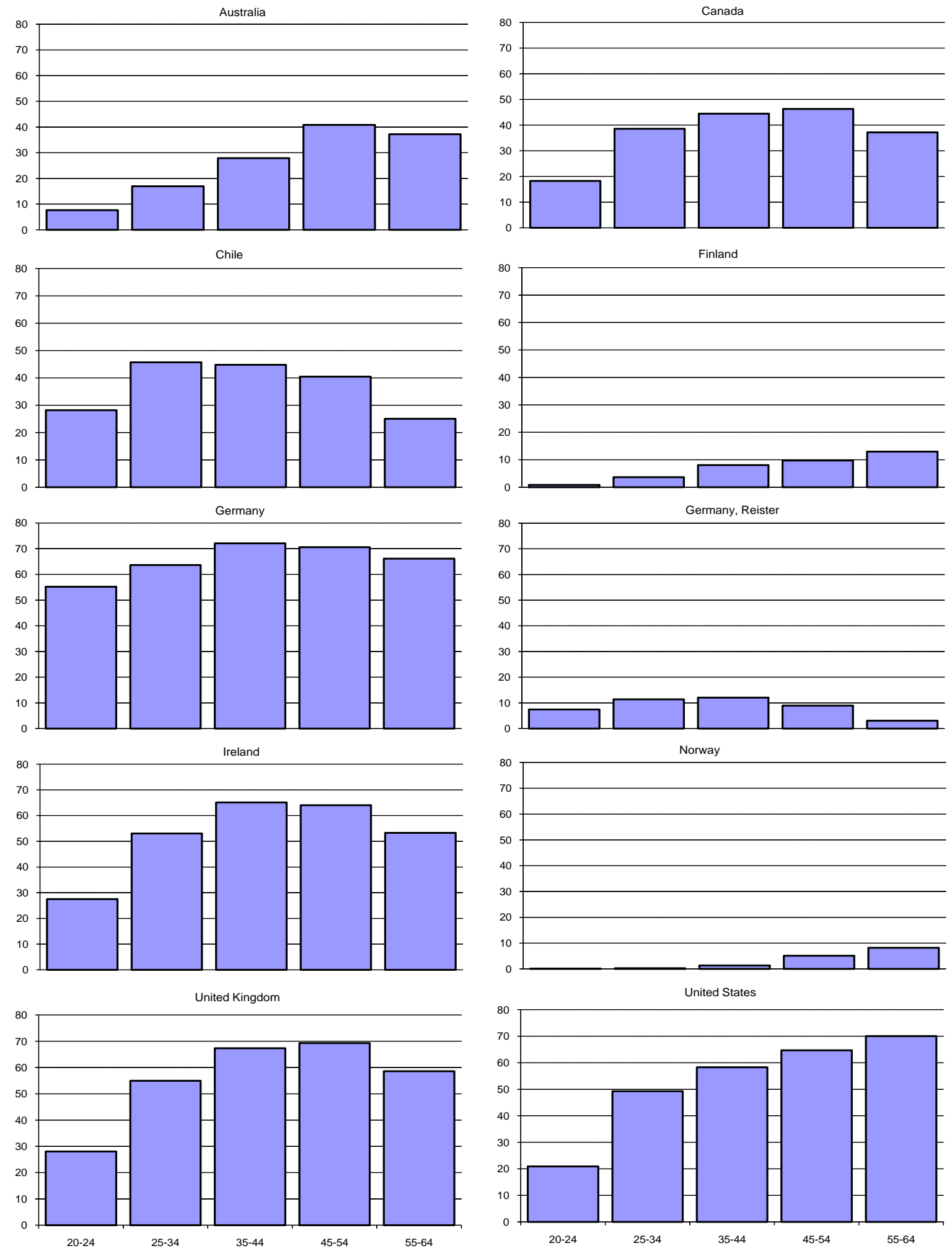

Source: OECD, Private Pension Unit (see Table 2).

Note: The data for Australia excludes individuals with only employer contributions (i.e. only individuals with voluntary contributions are included). The data for Canada refer to only occupational plans, i.e. RPP and group RRSP plans. 
Similarly, coverage increases with income (figure 6). In all the countries in the sample as income increases so does the coverage in funded pensions, reaching a plateau after the $7^{\text {th }}$ and $8^{\text {th }}$ deciles. In this context, coverage among the poorest income groups is quite low, at $10-20 \%$ in all countries, except in Germany (over 40\%). In the Riester pensions, coverage is higher for mid-income groups. Moreover, combining age and income, young people with low income are the ones at highest risk of insufficient old age income provision. 
Figure 6. Coverage in voluntary funded pension plans according to income

(\% of total employment)
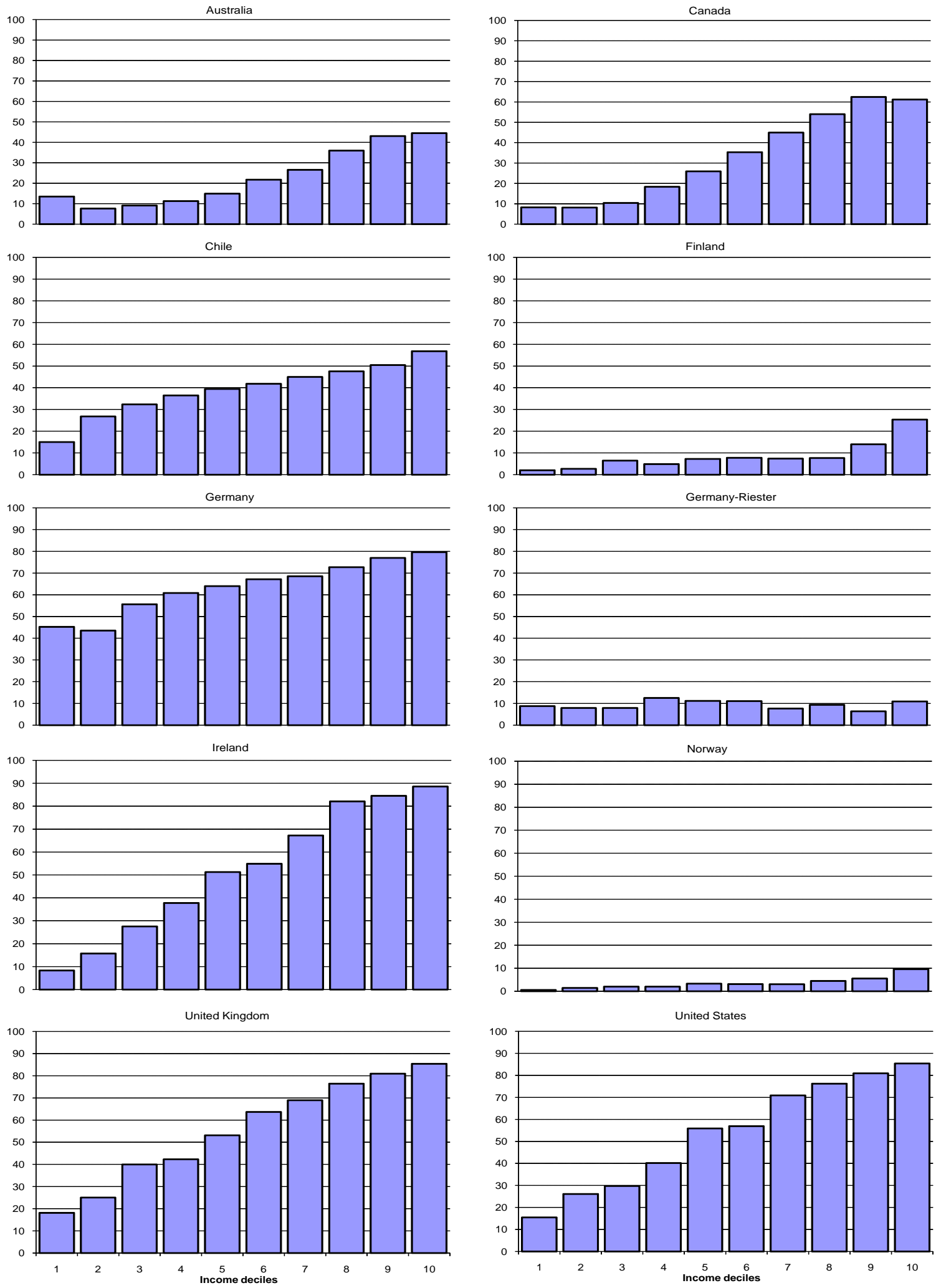

Source: OECD, Private Pension Unit (see Table 2).

Note: The data for Australia excludes individuals with only employer contributions (i.e. only individuals with voluntary contributions are included). The data for Canada refer to only occupational plans, i.e. RPP and group RRSP plans. 
The coverage rate is much higher for full-time than for part-time workers (figure 7) and for employees than self-employed (figure 8). It is almost double in the case of the United Kingdom and almost triple in the case of the United States. However, in Germany, people working part-time show a higher tendency to have a life insurance or being enrolled in a private pension plan than full-time workers. This same pattern is repeated when examining coverage in Riester pensions. This is most likely explained by the high replacement rates of PAYG-financed public pensions for full-time workers.

Figure 7. Coverage in voluntary funded pension plans according to full and part-time status (\% of total employment)

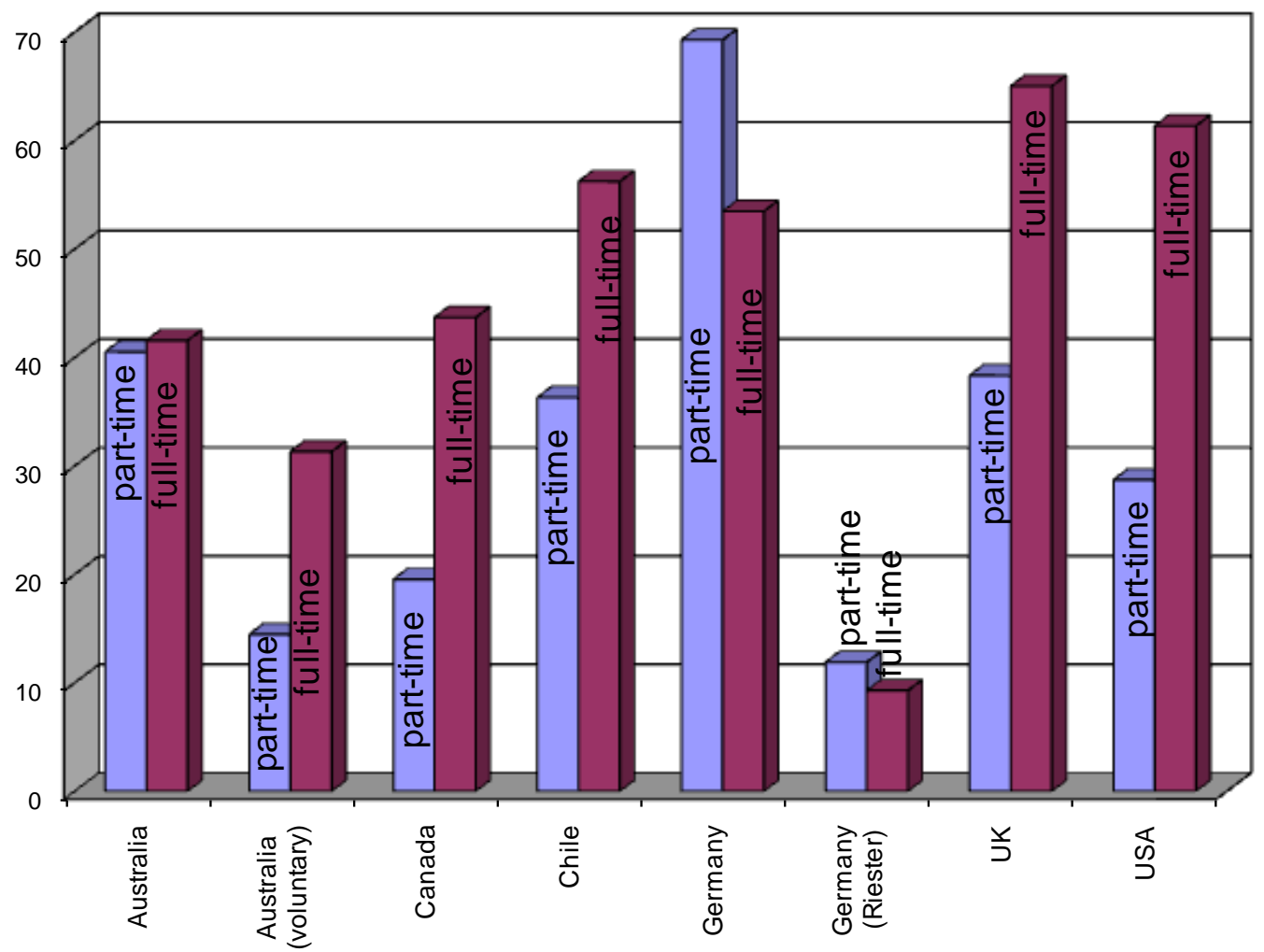

Source: OECD, Private Pension Unit (see Table 2).

Notes: The data in the first figure for Australia includes individuals enrolled in any superannuation fund with only employer contributions, while the second figure for Australia excludes individuals with only employer contributions. Those people who self-declare employees of their own businesses are classified as self-employed; however it is mandatory for their businesses to make contributions on their behalf. Hence the figures for self-employed Australians do not coincide in both columns. The figure for Germany refers only to the Riester pensions. The data for Canada refer to only occupational plans, i.e. RPP and group RRSP plans. 
It is interesting to compare the results on coverage for Australia when only considering voluntary contributions by employees and when including employers' compulsory contributions (figure 8). This comparison suggests that full-time employees have a higher coverage when enrolment is voluntary. In the case of the self-employed, the results for Australia suggest that they are as likely to make personal contributions as employees; the difference in their overall coverage is due to the compulsory nature of employers' contributions.

Moreover, the results from Finland and Norway suggest that the self-employed are more likely to enrol in voluntary funded pension plans than employees when PAYG-financed public pensions provide a relatively high replacement rate.

Figure 8. Coverage in voluntary funded pension plans according to their employment status (\% of total employment)

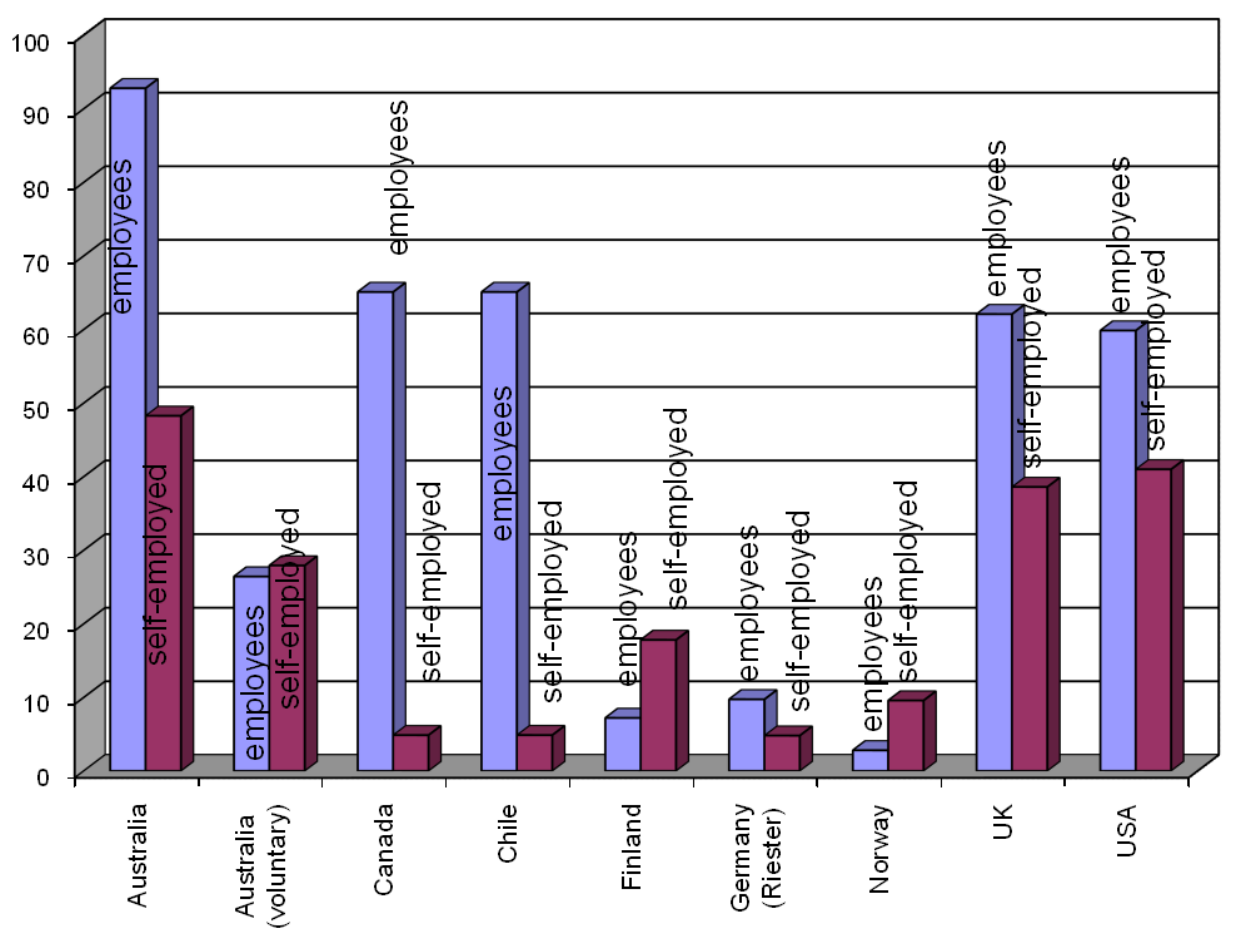

Source: OECD, Private Pension Unit (see Table 2).

Notes: The data in the first figure for Australia includes individuals enrolled in any superannuation fund with only employer contributions, while the second figure for Australia excludes individuals with only employer contributions. Those people who self-declare employees of their own businesses are classified as self-employed; however it is mandatory for their businesses to make contributions on their behalf. Hence the figures for self-employed Australians do not coincide in both columns. The figure for Germany refers only to the Riester pensions. The data for Canada refer to only occupational plans, i.e. RPP and group RRSP plans. 
Coverage rates in voluntary funded pension plans are relative larger for men than for women (figure 9). In Chile, due to lower rates of informality in women's employment, coverage is higher for women.

Figure 9. Coverage in voluntary funded pension plans according to their employment status (\% of total employment)

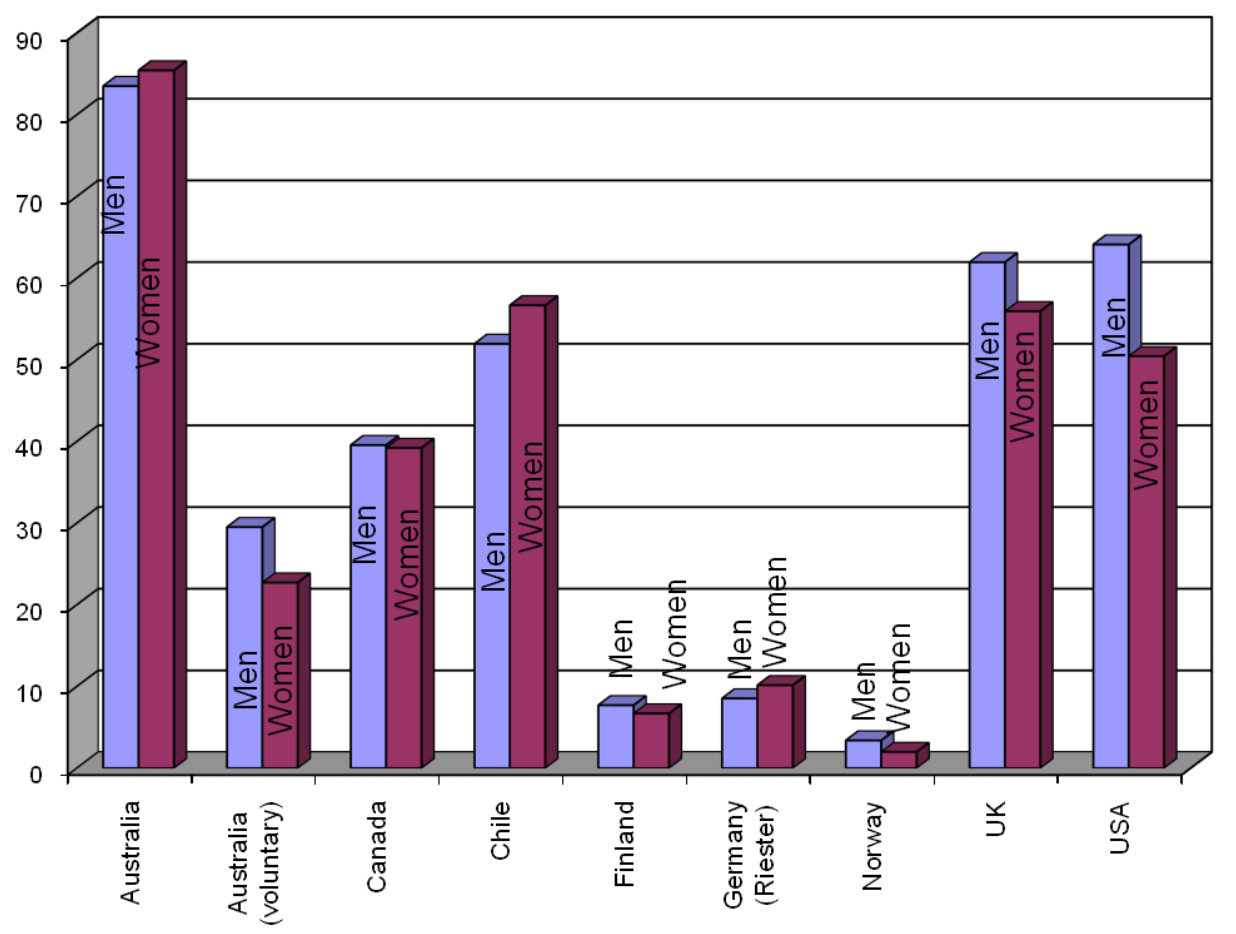

Source: OECD, Private Pension Unit (see Table 2).

Notes: The data in the first figure for Australia includes individuals enrolled in any superannuation fund with only employer contributions, while the second figure for Australia excludes individuals with only employer contributions. Those people who self-declare employees of their own businesses are classified as self-employed; however it is mandatory for their businesses to make contributions on their behalf. Hence the figures for self-employed Australians do not coincide in both columns. The figure for Germany refers only to the Riester pensions. The data for Canada refer to only occupational plans, i.e. RPP and group RRSP plans. 
Finally, people tend to be enrolled in more than one funded pension plan. The share of those in employment enrolled in funded pension plans that are enrolled in more than one plan varies from $7 \%$ in the United Kingdom and almost $14 \%$ in the United States to just over 22\% in Australia (figure 9). This confirms that using administrative data to estimate coverage requires adjusting for double counting.

Figure 10. People enrolled in more than one funded pension plan

(\% of those in employed enrolled)

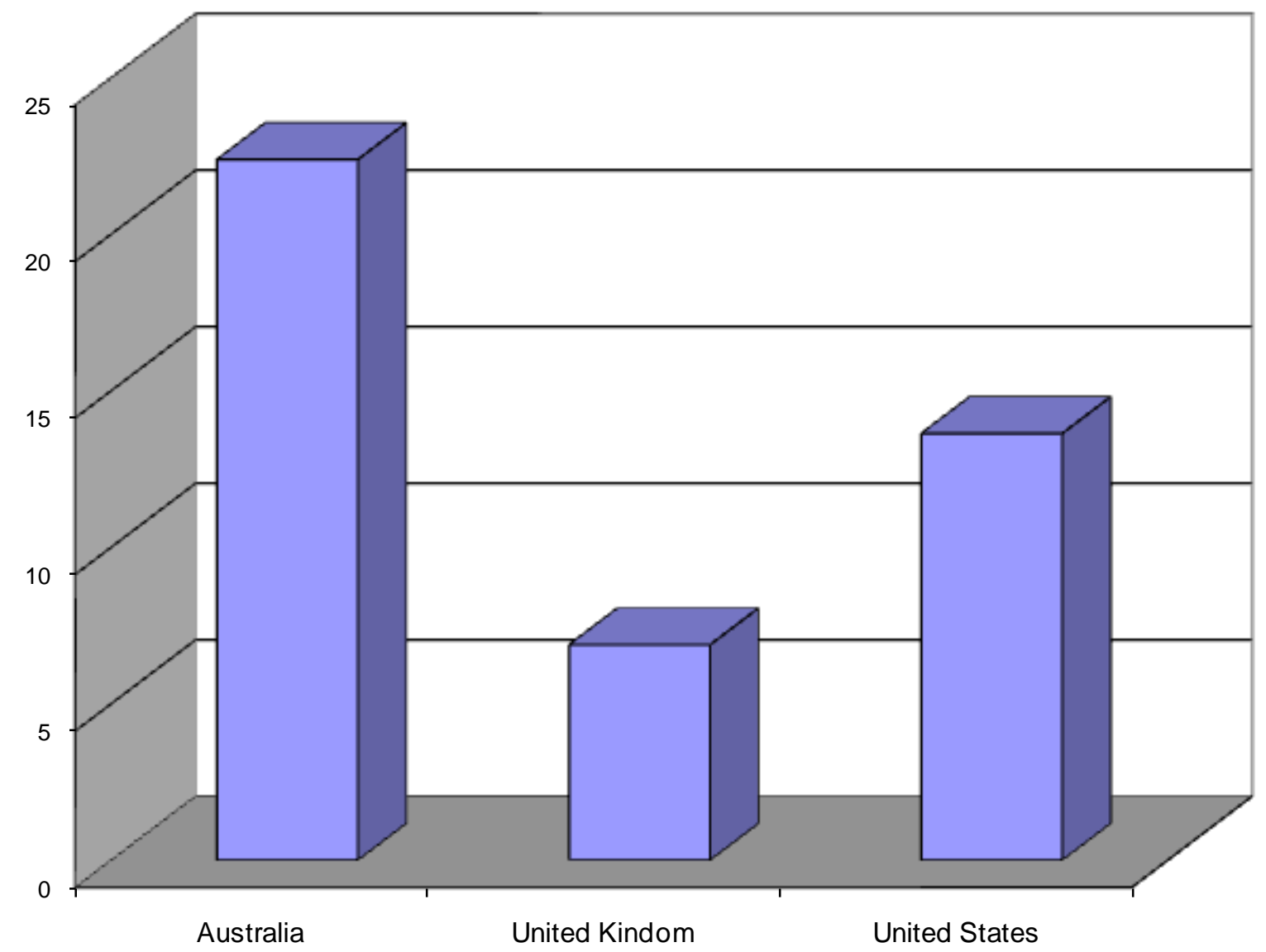

Source: OECD, Private Pension Unit (see Table 2).

In conclusion, coverage is uneven across individuals and it may need to increase, at least, for the midto-low income and young population subgroups. ${ }^{19}$ The results discussed above show that despite of enrolment rates in voluntary funded pension plans well above $50 \%$ in most of the countries considered, the coverage rate is unevenly distributed across individuals. Young cohorts and low income individuals experience much lower rates of enrolment. For instance, the data in the annex shows that enrolment rates are less than a third of the relevant employed population for individuals in the lowest fifth income deciles and younger than 25 (or in the lowest three income deciles for those younger than 35) in Canada, Ireland, the United Kingdom and the United States. The same pattern applies to Australia, although with lower coverage rates among those individuals making personal contributions to superannuation funds.

\footnotetext{
${ }^{19}$ However, in the case of low income households one could argue for increasing benefits from mandatory PAYGfunded pension plans as voluntary funded pensions are unlikely to be cost effective for this group.
} 


\section{Policy options to increase enrolment in voluntary funded pensions}

This section assesses policy options to increase coverage in voluntary funded pensions. Uneven enrolment rates in voluntary funded pension plans could be the result of differences in workers' access to occupational pension plans as well as differences in the set of incentives and alternatives faced by eligible workers. Options to overcome obstacles to achieve high and uniformly distributed levels of enrolment include compulsion, soft-compulsion, product regulation, financial education, better information disclosure, and improving eligibility and incentives for enrolment.

Several countries have achieved both high and uniformly distributed levels of coverage across age and income levels through compulsion. ${ }^{20}$ Yet, compulsion may need to be accompanied by labour market measures that reduce informality, otherwise, compulsion may not lead to universal coverage, as the case of Chile suggest. However, compulsion may not be an available policy option for some countries, not least because saving for retirement beyond certain threshold is considered an individual choice. Yet, when people are left by themselves to provide for retirement, empirical evidence suggests that some may not save enough for retirement.

Alternatively, high and uniformly distributed levels of coverage could be achieved through softcompulsion, in particular through automatic enrolment. It has been suggested that automatic enrolment in pension plans with appropriate default options with respect to contribution rates and investment allocation may achieve the dual goal of preserving individual choice and ensuring an adequate level of saving for retirement even if they do nothing. The recent findings from behavioural finance literature highlighting the importance role that "inertia" or "passive decision" plays in the decision to participate in retirement saving plans (Choi et al., 2002; Mitchell and Utkus, 2003; and Beshears et al., 2006), suggest that by changing the design of pension plans (e.g. 401(k) plans) and making enrolment the default option, enrolment in voluntary funded plans can be boosted substantially as few employees ever take action to disenroll. ${ }^{21}$ However, despite growing enthusiasm for automatic enrolment (e.g. New Zealand will introduce automatic enrolment in July 2007 and the United Kingdom has announced that it will do so in 2012) experience of its use and evidence of its impact is fairly limited and comes mainly from the United States. In this context, default options may also bring some problems. For example, as few workers opt out, the choices of default options made by governments or employers may create contingent liabilities. Additionally, default options may lead to low returns as pension funds may err on the side of cautiousness.

Nevertheless, enrolment can also be increased by improving eligibility and incentives for enrolment in funded pension plans. Eligibility to funded pension plans may play a significant role in explaining uneven coverage. In fact, data on sponsorship of pension plans by US firms indicate that for various reasons, lower-income workers are less likely to be employed by a firm that offers membership to funded plans (Copeland, 2003). ${ }^{22}$ Possible explanations in the literature include that low-skills, low-paid jobs may be more highly concentrated among small and medium-sized firms who may not have the financial muscle to

${ }^{20}$ Membership of funded pension plans is mandatory in Australia, Hungary, Iceland, Mexico, Poland, Slovak Republic, Sweden and Switzerland. However, self-employed as well as employees earning very low income are not subject to the mandatory rule in Australia and Switzerland. In Australia, only employers are obliged to contribute for employees to funded pension plans. In addition, Denmark, the Netherlands, Norway (from 2007) and Sweden have quasi-mandatory occupational pension plans, achieved via broad collective agreements between social partners. New Zealand, Italy and the United Kingdom have automatic enrolment.

${ }^{21}$ For instance, Madrian and Shea (2001), and Choi et al. (2002) have shown that participation is higher at firms where employees are automatically enrolled unless they signal their wish to opt out.

${ }^{22}$ Less than 50 per cent of workers with an annual income below $\$ 50,000$ are employed by a firm that sponsors a plan, whereas the sponsorship rate rises to 75 per cent for workers with earnings above that level. 
sponsor funded pension plans; ${ }^{23}$ and the relative decline in manufacturing jobs and along with it the decline in unionisation. ${ }^{24}$ On incentives, Beshears et al. (2006) argued that simplification of plan rules for eligibility and enrolment provides adequate incentives boosting enrolment, although these increases are not as large as those obtained by firms that automatically enrol their employees in a retirement saving plan.

Financial education can also be a means for improving coverage in voluntary funded pensions. National awareness campaigns have been shown to increase understanding of the pension system and the need to save, which should lead to greater coverage rates. In addition, employment based campaigns have been shown to increase participation and contribution rates in pension schemes (OECD 2005b). Agnew et al. (2007) find that financial literacy among workers in $401(\mathrm{~K})$ plans is positively associated with higher participation rates or lower rates of people opting out in automatic enrolment plans, underscoring the importance of outgoing workplace financial education for participants in both voluntary and automatic enrolment plans. Apart from improving financial literacy, and awareness about the need to save for retirement, more effective information disclosure could also help in improving coverage as individuals will be better placed to make a decision.

Additionally, strengthening the value of tax incentives embodied in funded pension plans for low and middle-income individuals could boost the enrolment rate for these population sub-groups. Tax-favoured schemes are design such that the tax incentives increase with income. Consequently, it is argued that replacing tax deductions with tax credits may just help achieving the goal of increasing coverage among mid-to-low income individuals, as tax credits may reshuffle tax incentives toward individual with lower income (Antolin and Lopez, 2008; Antolin et al., 2004).

Moreover, incentives for enrolment depend on the type of funded pension plans, i.e. whether they are occupational or personal plans. Given the potential difficulties for small and medium size enterprises to bear the administrative costs and responsibilities of sponsoring a pension plan, it is possible to increase coverage with personal plans. Personal plans may facilitate access to funded pension saving for part-time workers, for those whose labour market participation is intermittent, and for people working in firms without occupational plans. In addition, they are more portable than occupational plans as they are not attached to an employment relationship. However, occupational plans provide an important incentive for enrolment over personal plans as it is through them that employers provide matching contributions. ${ }^{25}$ Additionally, investment and management fees are generally lower in the case of occupational plans thanks to scale, pooling, and the not-for-profit nature of occupational pension funds.

${ }^{23}$ Sponsorship rate was around 68 per cent in US firms with 100 or more employees in 2002 . However, it felt to 28 per cent among firms with less than 100 employees. Additionally, while small and medium-sized firms account for 50 per cent of all employees, they account for less than 30 per cent of total eligible workers.

${ }^{24}$ Sponsorship in the United States is higher in manufacturing (63 per cent of all firms) than wholesale and retail trade or personal services (around 45 per cent on average). In Canada, Morissette and Drolet (2001) argued that the decline in occupational pension plan participation during the 1990s was been largely attributed to the relative decline of manufacturing sectors and the rise in administrative costs.

${ }^{25}$ Poterba (2003) argues that the possibility of matching contributions may partly explain the success of 401(k) plans in the United States relative to IRAs. 


\section{REFERENCES}

Agnew, J.R., L. Szykman, S.P. Utkus, and J.A. Young (2007), "Literacy, Trust and 401(K) saving behaviour", Center for Retirement Research WP 2007-10

Antolin, P., E. Lopez (2008), “The Impact of Tax Incentives on Retirement Savings” forthcoming OECD Working Paper on Insurance and Private Pensions.

Antolin, P., A. de Serres and C. de la Maissonneuve (2004), "Long-term budgetary implications of taxfavoured retirement saving plans", OECD Economic Studies No. 39, 2004/2

Bershears, J., J. Choi, D. Laibson and B.C. Madrian (2006), Simplification and saving, NBER Working Paper No. 12659

Copeland, C. (2003), "Employment-based retirement and pension plan participation: declining levels and geographic differences", EBRI Issue Brief No. 262

Choi, J., D. Laibson, B.C. Madrian and A. Metrick (2002), "Defined Contribution Plans: Plan Rules, Participant Decisions, and the Path of Least Resistance", Working Paper 2002-3, Pension Research Council, The Wharton School, University of Pennsylvania, Philadelphia, http://rider.wharton.upenn.edu/ prc/PRC/WP/WP2002-3.pdf.

Gale W. and J.W. Phillips (2006), "Pensions, Social Security, Wealth and Lifetime Earnings: Evidence from the Health and Retirement Study", Center for Retirement Research Working Paper 2006-14.

Lindbeck, A. and M. Persson (2003), “The Gains from Pension Reform”, Journal of Economic Literature, vol. XLI

Madrian, B. C. and D. F. Shea (2001), "The Power of Suggestion: Inertia in 401(k) participation and Saving Behaviour", Quarterly Journal of Economics, Vol. 116/4.

Mitchell, O. and S. Utkus (2003), Lessons from behavioral finance for retirement plan design, Pension Research Council Working Paper 2003-6, University of Pennsylvania.

Morissette, R. and M. Drolet (2001), "Pension coverage and retirement savings", Perspectives, Summer 2001, Statistics Canada.

OECD (1998), Maintaining Prosperity in an Ageing Society, OECD Paris

OECD (2005a), Private Pensions: An OECD Classification and Glossary, OECD Paris.

OECD (2005b), Improving Financial Literacy, OECD Paris

OECD (2007), Pensions at a Glance, OECD Paris.

Poterba, J. (2003), “Government policy and private retirement saving”, CES-Munich Prize lecture. 
Rofman, R. and L. Lucchetti (2006), "Pensions in Latin America: Concepts and Measurements of Coverage", World Bank Social Protection working paper No. 0616.

Vial, J. and A. Melguizo (2008), "Moving from PAYG to Privately Managed Individual Pension Account: What have we learned after 25 years of the Chilean Pension Reform? "BBVA Economic Research Department Working Paper 0805.

http://serviciodeestudios.bbva.com/TLBB/fbin/IINWP_0805_workingpapers_05_tcm268168641.pdf 


\section{ANNEX 1. TABLES ON COVERAGE ON FUNDED PENSION PLANS}

\section{Results for Australia from the Household, Income and Labour Dynamics in Australia survey (HILDA)}

\section{Total}

Table 1. Percentage of workers enrolled in any superannuation fund by age and income level, Australia, 2002

\begin{tabular}{|c|c|c|c|c|c|c|c|c|}
\hline \multirow[b]{2}{*}{ Income range (Deciles) } & \multirow[b]{2}{*}{$20-24$} & \multirow[b]{2}{*}{$25-34$} & \multirow[b]{2}{*}{$35-44$} & \multicolumn{2}{|c|}{ All Earners } & \multirow[b]{2}{*}{$\begin{array}{l}\text { All Working } \\
\text { age (20-64) }\end{array}$} & \multirow[b]{2}{*}{$65+$} & \multirow[b]{2}{*}{ All ages } \\
\hline & & & & $45-54$ & $55-64$ & & & \\
\hline 1 & 51.3 & 72.7 & 44.4 & 84.9 & 20.6 & 58.3 & 12.2 & 56.2 \\
\hline 2 & 47.9 & 58.8 & 49.1 & 58.0 & 17.8 & 48.6 & 9.1 & 46.8 \\
\hline 3 & 77.3 & 54.7 & 68.8 & 51.0 & 56.5 & 63.7 & 73.6 & 63.9 \\
\hline 4 & 89.7 & 77.3 & 81.3 & 73.9 & 62.1 & 79.0 & 20.3 & 78.1 \\
\hline 5 & 94.3 & 84.9 & 86.7 & 83.7 & 73.3 & 85.7 & 51.0 & 85.3 \\
\hline 6 & 94.9 & 86.8 & 92.6 & 86.9 & 87.9 & 89.5 & 44.3 & 89.3 \\
\hline 7 & 96.1 & 89.2 & 91.9 & 91.2 & 90.1 & 91.0 & 29.9 & 90.1 \\
\hline 8 & 92.5 & 95.4 & 89.3 & 91.7 & 88.0 & 91.8 & 78.6 & 91.7 \\
\hline 9 & 100.0 & 92.6 & 89.2 & 93.3 & 85.8 & 91.3 & 37.5 & 90.5 \\
\hline 10 & 89.7 & 90.9 & 90.3 & 89.2 & 81.8 & 88.9 & 49.5 & 88.3 \\
\hline Total (\% employment) & 86.9 & 85.9 & 86.2 & 85.6 & 75.7 & 85.0 & 41.0 & 84.4 \\
\hline
\end{tabular}

Table 2. Percentage of people aged 20 or more participating in any superannuation fund by age and employment status, Australia 2002

\begin{tabular}{|c|c|c|c|c|c|c|c|c|}
\hline Employment status & $20-24$ & $25-34$ & $35-44$ & $45-54$ & $55-64$ & $\begin{array}{l}\text { All Working } \\
\text { age }(20-64)\end{array}$ & $65+$ & All ages \\
\hline $\begin{array}{l}\text { Employed } \\
\text { of which }\end{array}$ & 86.9 & 85.9 & 86.2 & 85.6 & 75.7 & 85.0 & 41.0 & 84.4 \\
\hline part-time & 77.2 & 73.4 & 80.5 & 78.9 & 66.7 & 40.5 & 76.3 & 75.3 \\
\hline $\begin{array}{l}\text { full-time } \\
\text { of which }\end{array}$ & 92.5 & 89.4 & 88.4 & 87.9 & 80.7 & 41.6 & 88.3 & 87.9 \\
\hline employees & 88.5 & 93.1 & 94.8 & 93.9 & 89.1 & 92.8 & 66.5 & 92.6 \\
\hline self-employed & 37.6 & 36.0 & 49.3 & 55.3 & 49.3 & 48.3 & 14.6 & 47.1 \\
\hline non-employed & 1.9 & 6.2 & 6.1 & 8.9 & 5.6 & 5.9 & 0.0 & 5.7 \\
\hline of which unemployed: & 9.1 & 17.6 & 48.3 & 19.2 & 5.9 & 4.4 & 0.0 & 4.4 \\
\hline Total (\% working age & & & & & & & & \\
\hline population) & 74.6 & 77.2 & 78.0 & 79.7 & 67.7 & 76.7 & 33.4 & 76.0 \\
\hline
\end{tabular}

Table 3. Percentage of people aged 20 or more participating in any superannuation fund by age and gender, Australia 2002

\begin{tabular}{|c|c|c|c|c|c|c|c|c|}
\hline Employment status & $20-24$ & $25-34$ & $35-44$ & $45-54$ & $55-64$ & $\begin{array}{l}\text { All Working } \\
\text { age (20-64) }\end{array}$ & $65+$ & All ages \\
\hline Male & 85.7 & 86.2 & 85.8 & 85.0 & 73.0 & 84.4 & 38.8 & 83.5 \\
\hline Female & 88.2 & 85.5 & 86.7 & 86.3 & 79.6 & 85.8 & 46.6 & 85.4 \\
\hline Total & 86.9 & 85.9 & 86.2 & 85.6 & 75.7 & 85.0 & 41.0 & 84.4 \\
\hline
\end{tabular}

Source: Secretariat calculations from the Household of Income and Labour Dynamics in Australia survey (HILDA), wage 2 


\section{People contributing to occupational plans and personal plans}

Table 1. Percentage of workers contributing to a supperannuation fund or any personal superannuation fund by age and income level, Australia 2002

\begin{tabular}{|c|c|c|c|c|c|c|c|c|}
\hline \multirow[b]{2}{*}{ Income range (Deciles) } & \multicolumn{8}{|c|}{ All Earners } \\
\hline & $20-24$ & $25-34$ & $35-44$ & $45-54$ & $55-64$ & $\begin{array}{l}\text { All Working } \\
\text { age }(20-64)\end{array}$ & $65+$ & All ages \\
\hline 1 & 12.5 & 15.0 & 6.4 & 21.1 & 10.1 & 13.5 & 12.2 & 13.5 \\
\hline 2 & 2.5 & 3.1 & 7.9 & 20.3 & 5.6 & 7.6 & 0.0 & 7.3 \\
\hline 3 & 3.7 & 4.3 & 12.3 & 12.4 & 20.4 & 9.1 & 2.7 & 8.9 \\
\hline 4 & 4.4 & 2.0 & 15.6 & 21.7 & 14.7 & 11.3 & 8.0 & 11.2 \\
\hline 5 & 2.8 & 8.9 & 16.7 & 30.0 & 16.4 & 14.9 & 0.0 & 14.7 \\
\hline 6 & 13.3 & 16.3 & 20.7 & 29.5 & 36.7 & 21.8 & 21.9 & 21.8 \\
\hline 7 & 17.4 & 17.9 & 22.7 & 40.2 & 44.0 & 26.6 & 4.7 & 26.2 \\
\hline 8 & 14.7 & 22.5 & 38.5 & 48.9 & 51.4 & 35.9 & 58.0 & 36.2 \\
\hline 9 & 13.3 & 27.0 & 44.6 & 51.0 & 65.4 & 43.1 & 32.7 & 42.9 \\
\hline 10 & 9.7 & 26.7 & 39.0 & 61.2 & 47.4 & 44.5 & 17.2 & 44.1 \\
\hline Total (\% employment) & 7.7 & 16.9 & 27.9 & 40.8 & 37.2 & 26.7 & 15.1 & 26.5 \\
\hline
\end{tabular}

Table 2. Percentage of people aged 20 or more contributing to a supperannuation fund or any personal superannuation by age and employment status, Australia 2002

\begin{tabular}{|c|c|c|c|c|c|c|c|c|}
\hline Employment status & $20-24$ & $25-34$ & $35-44$ & $45-54$ & $55-64$ & $\begin{array}{l}\text { All Working } \\
\text { age }(20-64)\end{array}$ & $65+$ & All ages \\
\hline $\begin{array}{l}\text { employed } \\
\text { of which }\end{array}$ & 7.7 & 16.9 & 27.9 & 40.8 & $\overline{37.2}$ & 26.7 & 15.1 & $\overline{26.5}$ \\
\hline part-time & 2.9 & 5.6 & 15.5 & 27.3 & 18.1 & 14.5 & 6.0 & 14.2 \\
\hline $\begin{array}{l}\text { full-time } \\
\text { of which }\end{array}$ & 10.4 & 20.1 & 32.8 & 45.4 & 47.6 & 31.3 & 26.1 & 31.3 \\
\hline employed & 7.8 & 17.2 & 27.8 & 42.2 & 40.5 & 26.4 & 19.6 & 26.4 \\
\hline self-employed & 3.9 & 15.3 & 28.6 & 35.7 & 30.0 & 27.9 & 9.5 & 27.3 \\
\hline non-employed & 1.9 & 6.2 & 6.1 & 8.9 & 5.6 & 5.9 & 0.0 & 5.7 \\
\hline of which unemployed: & 9.1 & 17.6 & 48.3 & 19.2 & 5.9 & 4.4 & 0.0 & 4.4 \\
\hline $\begin{array}{c}\text { Total (\% working age } \\
\text { population) }\end{array}$ & 6.8 & 15.8 & 25.7 & 38.3 & 33.5 & 24.5 & 12.3 & 24.3 \\
\hline
\end{tabular}

Table 3. Percentage of people aged 20 or more contributing to a supperannuation fund or any personal superannuation by age and gender, Australia 2002

\begin{tabular}{|c|c|c|c|c|c|c|c|c|}
\hline Employment status & $20-24$ & $25-34$ & $35-44$ & $45-54$ & $55-64$ & $\begin{array}{l}\text { All Working } \\
\text { age }(20-64)\end{array}$ & $65+$ & All ages \\
\hline Male & 7.8 & 18.6 & 32.4 & 44.9 & 40.2 & 29.7 & 18.7 & 29.5 \\
\hline Female & 7.5 & 14.7 & 22.1 & 36.0 & 32.8 & 22.9 & 5.8 & 22.7 \\
\hline Total & 7.7 & 16.9 & 27.9 & 40.8 & 37.2 & 26.7 & 15.1 & 26.5 \\
\hline
\end{tabular}




\section{People contributing to occupational plans}

Table 1. Percentage of workers contributing to superannuation fund by age and income level, Australia 2002

\begin{tabular}{|c|c|c|c|c|c|c|c|c|c|}
\hline \multirow[b]{2}{*}{ Income range (Deciles) } & & \multicolumn{8}{|c|}{ All Earners } \\
\hline & & $20-24$ & $25-34$ & $35-44$ & $45-54$ & $55-64$ & $\begin{array}{l}\text { All Working } \\
\text { age }(20-64)\end{array}$ & $65+$ & All ages \\
\hline & 1 & 12.5 & 11.6 & 6.4 & 13.8 & 0.0 & 9.4 & 0.0 & 9.0 \\
\hline & 2 & 2.5 & 1.6 & 1.3 & 4.6 & 1.8 & 2.3 & 0.0 & 2.2 \\
\hline & 3 & 2.8 & 2.8 & 7.3 & 7.6 & 1.7 & 4.6 & 0.0 & 4.5 \\
\hline & 4 & 3.8 & 0.6 & 7.0 & 7.6 & 6.8 & 5.0 & 0.0 & 5.0 \\
\hline & 5 & 2.0 & 7.4 & 10.0 & 17.1 & 6.9 & 9.1 & 0.0 & 9.0 \\
\hline & 6 & 12.4 & 12.3 & 12.1 & 15.0 & 24.3 & 14.0 & 21.9 & 14.0 \\
\hline & 7 & 14.5 & 14.6 & 14.7 & 29.4 & 33.1 & 19.7 & 0.0 & 19.4 \\
\hline & 8 & 14.7 & 18.9 & 27.7 & 31.0 & 36.3 & 25.8 & 58.0 & 26.2 \\
\hline & 9 & 13.3 & 23.7 & 32.7 & 41.0 & 49.4 & 33.9 & 10.4 & 33.6 \\
\hline & 10 & 0.0 & 17.8 & 28.9 & 43.6 & 37.6 & 32.2 & 2.9 & 31.8 \\
\hline Total (\% employment) & & 6.7 & 13.4 & 18.9 & 27.4 & 25.4 & 18.8 & 8.1 & 18.6 \\
\hline
\end{tabular}

Table 2. Percentage of people aged 20 or more contributing to superannuation fund by age and employment status, Australia 2002

\begin{tabular}{|c|c|c|c|c|c|c|c|c|}
\hline Employment status & $20-24$ & $25-34$ & $35-44$ & $45-54$ & $55-64$ & $\begin{array}{l}\text { All Working } \\
\text { age }(20-64)\end{array}$ & $65+$ & All ages \\
\hline $\begin{array}{l}\text { employed } \\
\text { of which }\end{array}$ & 6.7 & 13.4 & 18.9 & 27.4 & 25.4 & 18.8 & 8.1 & 18.6 \\
\hline part-time & 1.9 & 3.8 & 8.8 & 14.6 & 8.4 & 7.9 & 2.3 & 7.8 \\
\hline of which & 9.4 & 16.1 & 22.9 & 31.8 & 34.8 & 22.8 & 15.0 & 22.8 \\
\hline employed & 6.9 & 15.2 & 22.0 & 33.0 & 34.6 & 21.6 & 15.9 & 21.5 \\
\hline self-employed & 0.0 & 1.2 & 5.5 & 6.9 & 7.7 & 5.4 & 0.0 & 5.2 \\
\hline $\begin{array}{l}\text { non-employed } \\
\text { of which unemployed: }\end{array}$ & 0.0 & 0.0 & 0.0 & 0.0 & 0.0 & 0.0 & 0.0 & 0.0 \\
\hline $\begin{array}{l}\text { Total (\% working age } \\
\text { population) }\end{array}$ & 5.7 & 12.0 & 17.0 & 25.3 & 22.5 & 16.8 & 6.6 & 16.6 \\
\hline
\end{tabular}

Table 3. Percentage of people aged 20 or more contributing to superannuation fund by age and gender, Australia 2002

\begin{tabular}{|c|c|c|c|c|c|c|c|c|}
\hline Employment status & $20-24$ & $25-34$ & $35-44$ & $45-54$ & $55-64$ & $\begin{array}{l}\text { All Working } \\
\text { age }(20-64)\end{array}$ & $65+$ & All ages \\
\hline Male & 6.7 & 14.0 & 21.3 & 29.4 & 27.3 & 20.3 & 10.7 & 20.1 \\
\hline Female & 6.6 & 12.7 & 15.8 & 25.0 & 22.8 & 16.8 & 1.3 & 16.7 \\
\hline Total & 6.7 & 13.4 & 18.9 & 27.4 & 25.4 & 18.8 & 8.1 & 18.6 \\
\hline
\end{tabular}

Source: Secretariat calculations from the Household of Income and Labour Dynamics in Australia survey (HILDA), wage 2 


\section{People contributing to personal plans}

Table 1. Percentage of workers contributing to private superannuation funds by age and income level, 2002

\begin{tabular}{|c|c|c|c|c|c|c|c|c|}
\hline \multirow[b]{2}{*}{ Income range (Deciles) } & \multicolumn{8}{|c|}{ All Earners } \\
\hline & $20-24$ & $25-34$ & $35-44$ & $45-54$ & $55-64$ & $\begin{array}{l}\text { All Working } \\
\text { age }(20-64)\end{array}$ & $65+$ & All ages \\
\hline 1 & 0.0 & 3.4 & 2.1 & 7.2 & 10.1 & 4.5 & 12.2 & 4.8 \\
\hline 2 & 0.0 & 1.6 & 6.6 & 15.7 & 3.8 & 5.4 & 0.0 & 5.1 \\
\hline 3 & 1.0 & 1.5 & 5.6 & 5.5 & 20.4 & 4.9 & 2.7 & 4.8 \\
\hline 4 & 0.6 & 1.4 & 9.0 & 15.8 & 7.8 & 6.7 & 8.0 & 6.7 \\
\hline 5 & 0.8 & 1.5 & 7.3 & 13.2 & 9.6 & 6.0 & 0.0 & 6.0 \\
\hline 6 & 1.0 & 5.0 & 8.7 & 14.9 & 14.6 & 8.4 & 0.0 & 8.3 \\
\hline 7 & 3.0 & 3.6 & 10.2 & 11.7 & 15.5 & 8.1 & 4.7 & 8.1 \\
\hline 8 & 0.0 & 3.6 & 14.5 & 23.5 & 20.2 & 13.1 & 0.0 & 12.9 \\
\hline 9 & 0.0 & 3.5 & 16.3 & 15.8 & 20.8 & 12.8 & 22.3 & 12.9 \\
\hline 10 & 9.7 & 10.2 & 11.6 & 24.7 & 16.4 & 16.2 & 14.3 & 16.2 \\
\hline Total (\% employment) & 1.0 & 3.8 & 10.9 & 16.8 & 15.0 & 9.7 & 7.0 & 9.7 \\
\hline
\end{tabular}

Table 2. Percentage of people aged 20 or more contributing to private superannuation funds by age and employment status, Australia 2002

\begin{tabular}{|c|c|c|c|c|c|c|c|c|}
\hline Employment status & $20-24$ & $25-34$ & $35-44$ & $45-54$ & $55-64$ & $\begin{array}{l}\text { All Working } \\
\text { age (20-64) }\end{array}$ & $65+$ & All ages \\
\hline $\begin{array}{l}\text { employed } \\
\text { of which }\end{array}$ & 1.0 & $\overline{3.8}$ & $\overline{10.9}$ & 16.8 & 15.0 & 9.7 & $\overline{7.0}$ & 9.7 \\
\hline part-time & 1.0 & 1.8 & 7.1 & 13.6 & 11.0 & 7.0 & 3.6 & 6.9 \\
\hline full-time & 1.0 & 4.4 & 12.3 & 17.9 & 17.1 & 10.7 & 11.1 & 10.7 \\
\hline of which & & & & & & & & \\
\hline employed & 0.9 & 2.4 & 7.8 & 13.2 & 9.8 & 6.7 & 3.7 & 6.7 \\
\hline self-employed & 3.9 & 14.2 & 24.4 & 29.7 & 24.4 & 23.6 & 9.5 & 23.1 \\
\hline non-employed & 1.9 & 6.2 & 6.1 & 8.9 & 5.6 & 5.9 & 0.0 & 5.7 \\
\hline of which unemployed: & 9.1 & 17.6 & 48.3 & 19.2 & 5.9 & 4.4 & 0.0 & 4.4 \\
\hline Total (\% working age & & & & & & & & \\
\hline population) & 1.1 & 4.1 & 10.4 & 16.2 & 13.9 & 9.3 & 5.7 & 9.2 \\
\hline
\end{tabular}

Table 3. Percentage of people aged 20 or more contributing to private superannuation funds by age and gender, Australia 2002

\begin{tabular}{|c|c|c|c|c|c|c|c|c|}
\hline Employment status & $20-24$ & $25-34$ & $35-44$ & $45-54$ & $55-64$ & $\begin{array}{l}\text { All Working } \\
\text { age (20-64) }\end{array}$ & $65+$ & All ages \\
\hline Male & 1.1 & 5.2 & 13.6 & 19.9 & 15.5 & 11.6 & 8.0 & 11.6 \\
\hline Female & 0.9 & 2.1 & 7.2 & 13.1 & 14.2 & 7.2 & 4.5 & 7.2 \\
\hline Total & 1.0 & 3.8 & 10.9 & 16.8 & 15.0 & 9.7 & 7.0 & 9.7 \\
\hline
\end{tabular}

Source: Secretariat calculations from the Household of Income and Labour Dynamics in Australia survey (HILDA), wage 2 


\section{Results for Canada using the Canadian Survey of Labour and Income Dynamics (SLID), 2005.}

Table 1. Percentage of workers participating in employer-sponsored pension plans by age and income level, 2005

\begin{tabular}{|c|c|c|c|c|c|c|c|c|c|}
\hline \multirow{2}{*}{\multicolumn{2}{|c|}{ Income range (deciles) }} & \multirow[b]{2}{*}{$20-24$} & \multirow[b]{2}{*}{$25-34$} & \multicolumn{3}{|c|}{ All Earners } & \multirow[b]{2}{*}{$\begin{array}{l}\text { All Working } \\
\text { age }(20-64)\end{array}$} & \multirow[b]{2}{*}{$65+$} & \multirow[b]{2}{*}{ All ages } \\
\hline & & & & $35-44$ & $45-54$ & $55-64$ & & & \\
\hline & 1.0 & 6.0 & 7.0 & 14.7 & 7.0 & 7.9 & 8.2 & 12.9 & 8.2 \\
\hline & 2.0 & 10.6 & 7.7 & 7.5 & 6.1 & 5.5 & 8.2 & 3.7 & 8.1 \\
\hline & 3.0 & 11.1 & 11.2 & 9.3 & 9.4 & 11.9 & 10.5 & 2.5 & 10.4 \\
\hline & 4.0 & 15.3 & 22.3 & 18.1 & 17.4 & 18.9 & 18.6 & 2.0 & 18.3 \\
\hline & 5.0 & 21.4 & 28.3 & 27.9 & 25.7 & 24.9 & 26.3 & 6.4 & 25.9 \\
\hline & 6.0 & 35.8 & 34.4 & 31.8 & 42.5 & 33.3 & 35.6 & 9.0 & 35.3 \\
\hline & 7.0 & 45.2 & 44.2 & 46.2 & 47.6 & 41.7 & 45.4 & 16.2 & 44.9 \\
\hline & 8.0 & 48.9 & 55.9 & 56.9 & 57.3 & 42.0 & 54.7 & 15.2 & 54.0 \\
\hline & 9.0 & 47.0 & 61.2 & 64.3 & 67.0 & 57.0 & 63.1 & 12.8 & 62.5 \\
\hline & 10.0 & 56.8 & 58.5 & 64.1 & 64.4 & 54.2 & 61.8 & 19.6 & 61.2 \\
\hline \multicolumn{2}{|l|}{ All income groups: } & 18.3 & 38.6 & 44.5 & 46.3 & 37.2 & 39.8 & 11.5 & 39.4 \\
\hline \multicolumn{2}{|l|}{ Employment status } & $20-24$ & $25-34$ & $35-44$ & $45-54$ & $55-64$ & $\begin{array}{l}\text { All working } \\
\text { age }(20-65)\end{array}$ & \multicolumn{2}{|r|}{ All ages } \\
\hline \multicolumn{2}{|l|}{$\begin{array}{l}\text { part-time } \\
\text { full-time }\end{array}$} & $\begin{array}{l}12.3 \\
21.8\end{array}$ & $\begin{array}{l}19.6 \\
42.1\end{array}$ & $\begin{array}{l}23.6 \\
47.9\end{array}$ & $\begin{array}{l}24.8 \\
49.7\end{array}$ & $\begin{array}{l}20.6 \\
42.0\end{array}$ & $\begin{array}{l}20.1 \\
44.0\end{array}$ & $\begin{array}{r}6.2 \\
15.6\end{array}$ & $\begin{array}{l}19.6 \\
43.7\end{array}$ \\
\hline \multicolumn{2}{|l|}{ Total } & 19.0 & 39.3 & 45.0 & 46.9 & 37.7 & 40.5 & 11.6 & 40.1 \\
\hline & & $20-24$ & $25-34$ & $35-44$ & $45-54$ & $55-64$ & $\begin{array}{l}\text { All working } \\
\text { age }(20-65)\end{array}$ & $65+$ & All ages \\
\hline male & & 19.5 & 38.4 & 44.4 & 46.9 & 37.1 & 40.1 & 9.2 & 39.6 \\
\hline female & & 17.0 & 38.8 & 44.6 & 45.6 & 37.3 & 39.5 & 15.7 & 39.2 \\
\hline Total & & 18.3 & 38.6 & 44.5 & 46.3 & 37.2 & 39.8 & 11.5 & 39.4 \\
\hline
\end{tabular}

Includes registered pension plans (RPP) and group registered retirement saving plans (group RRSP) 
Table 1. Percentage of workers participating in registered pension plans (RPP) by age and income level, 2005

\begin{tabular}{|c|c|c|c|c|c|c|c|c|}
\hline \multirow[b]{2}{*}{ Income range (Deciles) } & \multirow[b]{2}{*}{$20-24$} & \multirow[b]{2}{*}{$25-34$} & \multirow[b]{2}{*}{$35-44$} & \multicolumn{2}{|c|}{ All Earners } & \multirow[b]{2}{*}{$\begin{array}{l}\text { All Working } \\
\text { age (20-64) }\end{array}$} & \multirow[b]{2}{*}{$65+$} & \multirow[b]{2}{*}{ All ages } \\
\hline & & & & $45-54$ & $55-64$ & & & \\
\hline 1.0 & 3.4 & 7.0 & 14.0 & 5.8 & 7.9 & 7.0 & 0.0 & 6.9 \\
\hline 2.0 & 6.4 & 5.9 & 4.3 & 4.7 & 4.5 & 5.5 & 3.7 & 5.5 \\
\hline 3.0 & 8.3 & 9.5 & 7.6 & 7.6 & 10.0 & 8.5 & 2.5 & 8.4 \\
\hline 4.0 & 12.0 & 16.7 & 12.0 & 14.1 & 13.2 & 13.8 & 2.0 & 13.6 \\
\hline 5.0 & 16.7 & 22.8 & 23.1 & 20.5 & 18.0 & 21.0 & 4.5 & 20.7 \\
\hline 6.0 & 29.8 & 27.3 & 26.0 & 37.4 & 27.8 & 29.6 & 7.9 & 29.3 \\
\hline 7.0 & 36.5 & 35.4 & 38.4 & 41.7 & 34.3 & 37.8 & 12.4 & 37.4 \\
\hline 8.0 & 35.6 & 46.2 & 49.3 & 50.3 & 36.4 & 46.8 & 13.0 & 46.2 \\
\hline 9.0 & 38.2 & 50.0 & 54.5 & 57.7 & 51.2 & 53.7 & 12.0 & 53.2 \\
\hline 10.0 & 49.3 & 46.3 & 55.3 & 56.2 & 47.6 & 53.1 & 18.9 & 52.6 \\
\hline All income Groups & 13.8 & 31.1 & 37.5 & 40.1 & 31.8 & 33.4 & 9.7 & 33.1 \\
\hline Employment status & $20-24$ & $25-34$ & $35-44$ & $45-54$ & $55-64$ & $\begin{array}{l}\text { All working } \\
\text { age }(20-65)\end{array}$ & $65+$ & All ages \\
\hline part-time & 8.7 & 15.9 & 20.6 & 22.9 & 17.6 & 17.1 & 5.5 & 16.6 \\
\hline full-time & 16.7 & 34.0 & 40.4 & 42.9 & 35.7 & 36.9 & 13.7 & 36.7 \\
\hline Total & 14.3 & 31.7 & 38.0 & 40.7 & 32.2 & 34.0 & 10.2 & 33.6 \\
\hline & $20-24$ & $25-34$ & $35-44$ & $45-54$ & $55-64$ & $\begin{array}{l}\text { All working } \\
\text { age (20-65) }\end{array}$ & $65+$ & All ages \\
\hline male & 14.9 & 29.9 & 36.7 & 40.0 & 32.3 & 33.1 & 7.5 & 32.7 \\
\hline female & 12.7 & 32.4 & 38.5 & 40.2 & 31.2 & 33.7 & 14.0 & 33.5 \\
\hline Total & 13.8 & 31.1 & 37.5 & 40.1 & 31.8 & 33.4 & 9.7 & 33.1 \\
\hline
\end{tabular}




\section{Results from Chile, 2003}

Table 1. Percentage of people aged 20 or more participating in private pension plans by age and income decile, year

\begin{tabular}{|c|c|c|c|c|c|c|c|c|c|}
\hline \multirow{2}{*}{ Income decile } & & \multirow[b]{2}{*}{$20-24$} & \multirow[b]{2}{*}{$25-34$} & \multirow[b]{2}{*}{$35-44$} & \multicolumn{5}{|c|}{ All working } \\
\hline & & & & & $45-54$ & $55-64$ & Age (20-64) & $65+$ & All Ages \\
\hline$x^{2}$ & 1 & $9.8 \%$ & $15.7 \%$ & $18.5 \%$ & $16.0 \%$ & $8.9 \%$ & $15.0 \%$ & $1.2 \%$ & $13.3 \%$ \\
\hline & 2 & $19.5 \%$ & $27.3 \%$ & $33.6 \%$ & $27.3 \%$ & $14.7 \%$ & $26.8 \%$ & $2.6 \%$ & $24.2 \%$ \\
\hline & 3 & $23.3 \%$ & $37.4 \%$ & $39.5 \%$ & $32.2 \%$ & $14.6 \%$ & $32.3 \%$ & $4.0 \%$ & $28.8 \%$ \\
\hline & 4 & $29.6 \%$ & $42.1 \%$ & $41.8 \%$ & $36.2 \%$ & $20.9 \%$ & $36.5 \%$ & $4.9 \%$ & $33.1 \%$ \\
\hline & 5 & $35.3 \%$ & $45.9 \%$ & $45.7 \%$ & $38.7 \%$ & $20.0 \%$ & $39.4 \%$ & $3.7 \%$ & $34.6 \%$ \\
\hline & 6 & $37.2 \%$ & $50.8 \%$ & $47.4 \%$ & $39.0 \%$ & $24.4 \%$ & $41.8 \%$ & $4.2 \%$ & $36.3 \%$ \\
\hline & 7 & $37.0 \%$ & $55.4 \%$ & $53.9 \%$ & $41.7 \%$ & $26.0 \%$ & $45.0 \%$ & $6.8 \%$ & $40.2 \%$ \\
\hline & 8 & $33.5 \%$ & $57.4 \%$ & $56.5 \%$ & $51.4 \%$ & $26.6 \%$ & $47.5 \%$ & $6.6 \%$ & $42.3 \%$ \\
\hline & 9 & $29.6 \%$ & $61.3 \%$ & $59.5 \%$ & $49.9 \%$ & $35.3 \%$ & $50.4 \%$ & $8.9 \%$ & $45.2 \%$ \\
\hline & 10 & $18.3 \%$ & $63.9 \%$ & $65.7 \%$ & $65.0 \%$ & $48.4 \%$ & $56.8 \%$ & $11.6 \%$ & $51.8 \%$ \\
\hline Total & & $28.1 \%$ & $45.7 \%$ & $44.8 \%$ & $40.5 \%$ & $25.1 \%$ & $39.1 \%$ & $5.4 \%$ & $34.9 \%$ \\
\hline
\end{tabular}

Source: CASEN (2003)

Table 2. Percentage of people aged 20 or more participating in private pension plans by age and employment status, year

\begin{tabular}{|c|c|c|c|c|c|c|c|c|}
\hline Employment Status & $20-24$ & $25-34$ & $35-44$ & $45-54$ & $55-64$ & $\begin{array}{l}\text { All working } \\
\text { Age }(20-64)\end{array}$ & $65+$ & All Ages \\
\hline $\begin{array}{l}\text { employed: } \\
\text { of which }\end{array}$ & $68.2 \%$ & $70.9 \%$ & $59.7 \%$ & $44.9 \%$ & $27.2 \%$ & $55.7 \%$ & $3.5 \%$ & $53.6 \%$ \\
\hline part-time & $42.3 \%$ & $47.7 \%$ & $42.3 \%$ & $32.0 \%$ & $17.0 \%$ & $38.2 \%$ & $1.8 \%$ & $36.3 \%$ \\
\hline full-time & $73.6 \%$ & $74.3 \%$ & $62.2 \%$ & $46.7 \%$ & $28.7 \%$ & $58.3 \%$ & $3.9 \%$ & $56.2 \%$ \\
\hline of which & & & & & & & & \\
\hline employees & $77.1 \%$ & $77.3 \%$ & $73.8 \%$ & $54.2 \%$ & $40.1 \%$ & $67.1 \%$ & $4.7 \%$ & $65.1 \%$ \\
\hline self-employed & $1.5 \%$ & $6.9 \%$ & $4.8 \%$ & $7.0 \%$ & $3.8 \%$ & $5.1 \%$ & $1.3 \%$ & $4.9 \%$ \\
\hline non-employed & $22.4 \%$ & $33.8 \%$ & $30.4 \%$ & $19.5 \%$ & $6.3 \%$ & $22.8 \%$ & $0.2 \%$ & $15.7 \%$ \\
\hline of which unemployed: & $68.3 \%$ & $72.2 \%$ & $60.1 \%$ & $44.9 \%$ & $26.9 \%$ & $62.3 \%$ & $3.2 \%$ & $61.6 \%$ \\
\hline Total & $43.6 \%$ & $59.2 \%$ & $51.2 \%$ & $37.4 \%$ & $17.7 \%$ & $44.0 \%$ & $0.7 \%$ & $37.1 \%$ \\
\hline
\end{tabular}

Source: National Labor Survey INE \& SAFP

Table 3. Percentage of people aged 20 or more participating in employer-sponsored pension planss by age and gender

\begin{tabular}{|c|c|c|c|c|c|c|c|c|}
\hline & $20-24$ & $25-34$ & $35-44$ & $45-54$ & $55-64$ & $\begin{array}{l}\text { All working } \\
\text { age }(20-65)\end{array}$ & $65+$ & All ages \\
\hline male & $66.7 \%$ & $68.9 \%$ & $59.0 \%$ & $44.3 \%$ & $27.2 \%$ & $54.2 \%$ & $3.3 \%$ & $52.0 \%$ \\
\hline female & $70.5 \%$ & $74.3 \%$ & $61.0 \%$ & $46.1 \%$ & $27.2 \%$ & $58.3 \%$ & $3.9 \%$ & $56.7 \%$ \\
\hline Total & $68.2 \%$ & $70.9 \%$ & $59.7 \%$ & $44.9 \%$ & $27.2 \%$ & $55.7 \%$ & $3.5 \%$ & $53.6 \%$ \\
\hline
\end{tabular}




\section{Results for Finland using the Luxembourg Wealth Study Data Set, 1998}

Table 1. Percentage of workers participating in annuities and other deferred profit plans by age and income level, 1998

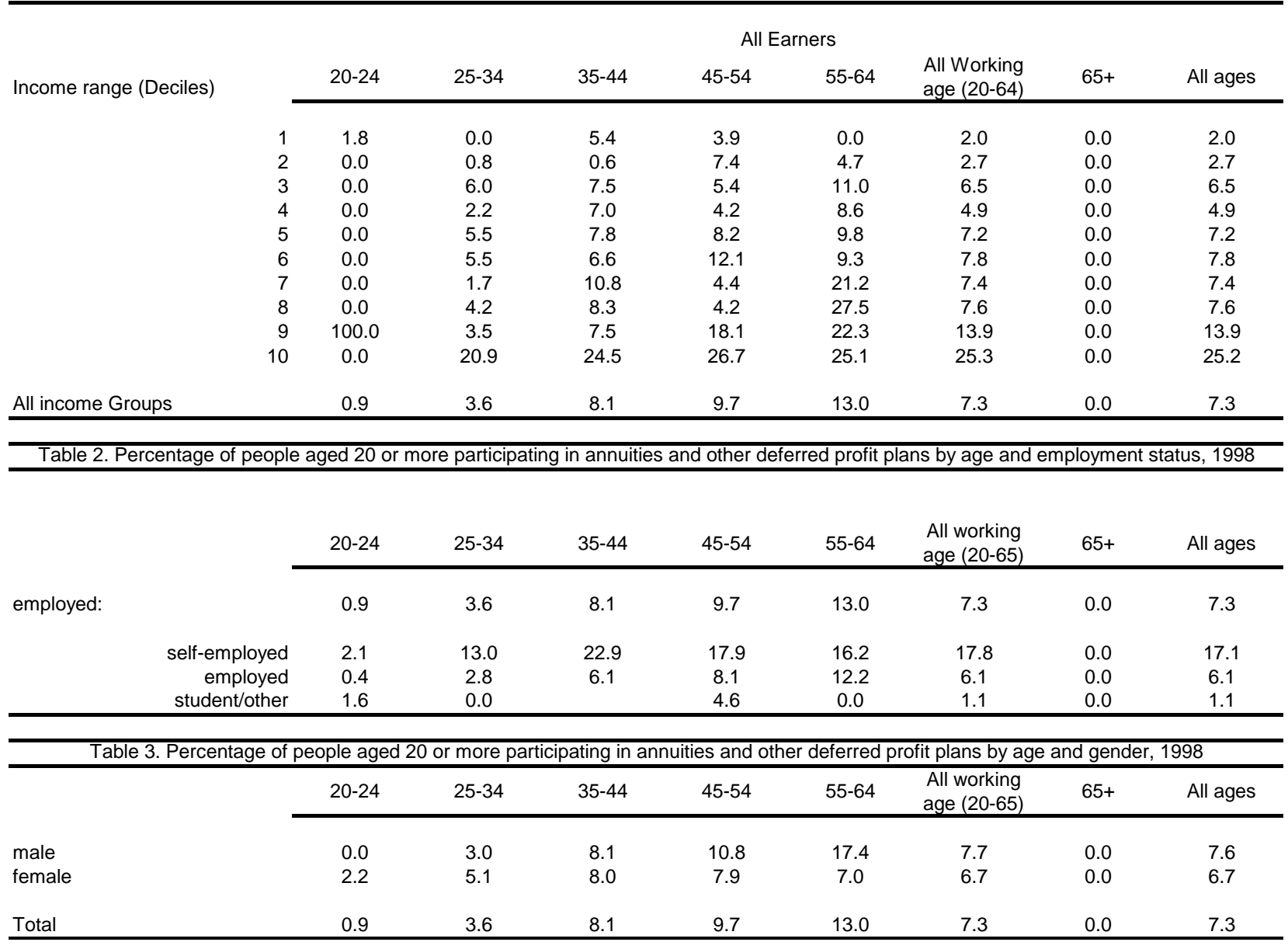




\section{Results for Germany using the German Socio-Economic Panel Data (GSOEP)}

\section{People with life insurance and private pensions}

Table 1. Percentage of employed people who have a life insurance, private pensions, etc. by age and income level, 2002

\begin{tabular}{|c|c|c|c|c|c|c|c|c|}
\hline \multirow[b]{2}{*}{ Income range (Deciles) } & \multicolumn{7}{|c|}{ All Earners } & \multirow[b]{2}{*}{ All ages } \\
\hline & $20-24$ & $25-34$ & $35-44$ & $45-54$ & $55-64$ & $\begin{array}{l}\text { All Working } \\
\text { age (20-64) }\end{array}$ & $65+$ & \\
\hline 1 & 34.4 & 42.2 & 49.9 & 55.0 & 74.7 & 48.3 & 19.4 & 45.3 \\
\hline 2 & 48.1 & 27.1 & 46.4 & 50.7 & 53.5 & 45.0 & 5.2 & 43.5 \\
\hline 3 & 59.0 & 49.9 & 61.7 & 58.0 & 52.0 & 56.0 & 11.1 & 55.6 \\
\hline 4 & 54.4 & 53.8 & 65.6 & 65.3 & 61.2 & 61.0 & 2.8 & 60.8 \\
\hline 5 & 57.6 & 59.8 & 66.6 & 69.0 & 59.9 & 63.9 & 77.1 & 64.0 \\
\hline 6 & 56.2 & 67.5 & 70.3 & 68.7 & 61.3 & 67.3 & 51.4 & 67.2 \\
\hline 7 & 68.7 & 67.0 & 73.4 & 64.9 & 68.1 & 68.5 & 100.0 & 68.5 \\
\hline 8 & 71.5 & 68.3 & 78.2 & 72.0 & 66.7 & 72.7 & 46.1 & 72.7 \\
\hline 9 & 71.1 & 76.8 & 79.6 & 76.9 & 71.1 & 77.1 & 71.3 & 77.0 \\
\hline 10 & 47.7 & 80.4 & 80.3 & 82.2 & 75.2 & 79.7 & 71.3 & 79.6 \\
\hline Total & 55.2 & 63.7 & 72.1 & 70.6 & 66.2 & 68.2 & 40.5 & 67.9 \\
\hline \multirow{2}{*}{$\begin{array}{l}\text { Employment status } \\
\text { employed: }\end{array}$} & $20-24$ & $25-34$ & $35-44$ & $45-54$ & $55-64$ & $\begin{array}{l}\text { All working } \\
\text { age (20-64) }\end{array}$ & $65+$ & All ages \\
\hline & 55.2 & 63.7 & 72.1 & 70.6 & 66.2 & 68.2 & 40.5 & 67.9 \\
\hline part-time: & 54.7 & 70.4 & 68.4 & 78.7 & 65.7 & 71.3 & 12.3 & 69.3 \\
\hline full-time: & 38.9 & 46.3 & 58.9 & 57.3 & 63.7 & 53.9 & 21.9 & 53.5 \\
\hline non-employed: & 31.6 & 44.8 & 53.4 & 50.7 & 59.5 & 47.0 & 31.4 & 45.9 \\
\hline unemployed & 9.5 & 21.7 & 17.7 & 13.4 & 30.3 & 44.5 & 7.4 & 43.4 \\
\hline Total & 40.7 & 59.2 & 69.1 & 67.7 & 64.0 & 63.1 & 34.1 & 62.3 \\
\hline
\end{tabular}




\section{People with Riester pension}

Table 1. Percentage of workers who possess a Riester-pension since 2002 by age and income level, 2004

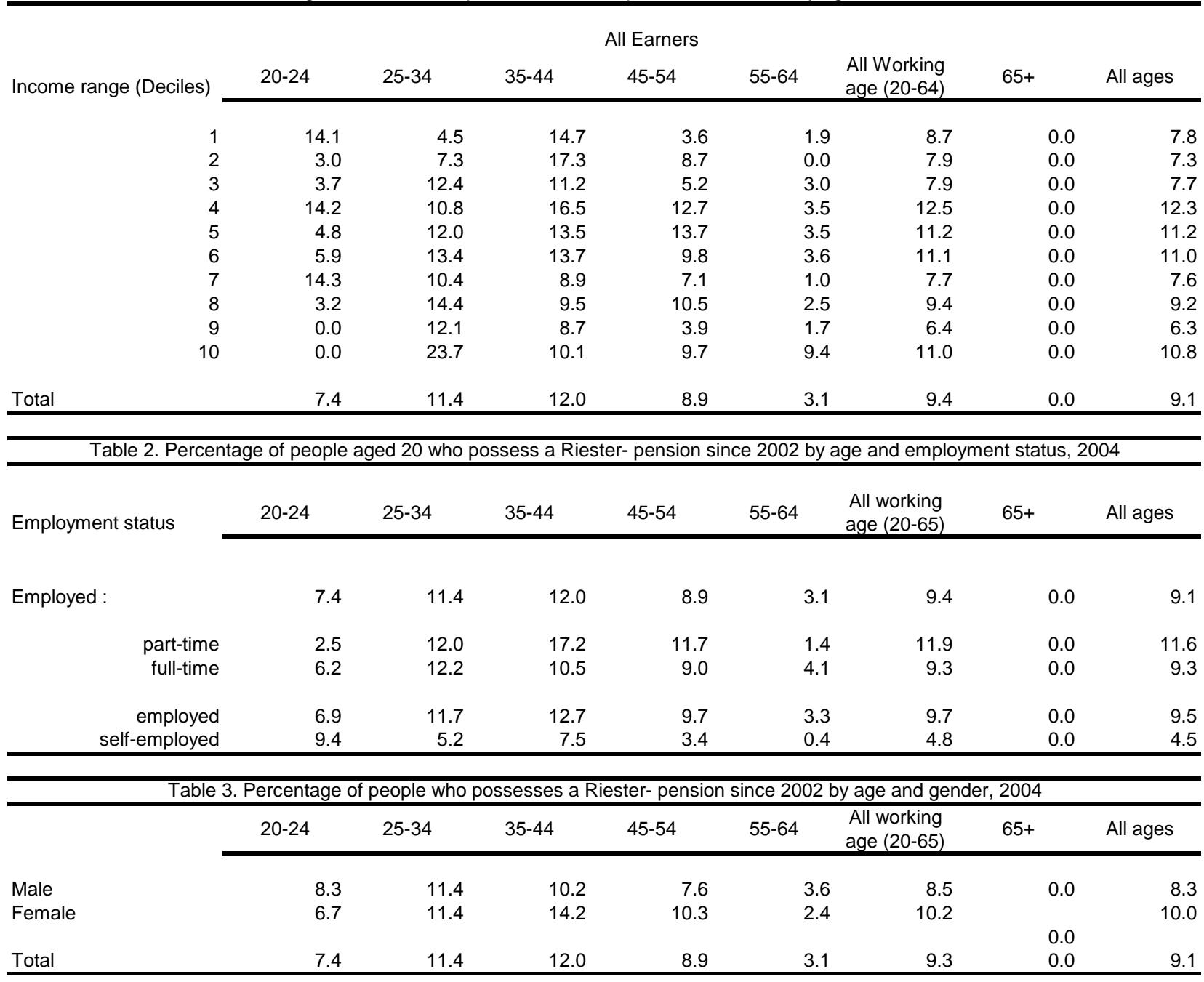




\section{Results for Great Britain (England, Wales and Scotland) from the British Household Panel Survey}

\section{Total}

Table 1. Percentage of people employed participating in private pension schemes by age and income level, 2004

\begin{tabular}{|c|c|c|c|c|c|c|c|c|}
\hline \multirow[b]{2}{*}{ Income range (Deciles) } & \multicolumn{8}{|c|}{ All Earners } \\
\hline & $20-24$ & $25-34$ & $35-44$ & $45-54$ & $55-64$ & $\begin{array}{l}\text { All Working } \\
\text { age (20-64) }\end{array}$ & $65+$ & All ages \\
\hline 1 & 5.5 & 11.4 & 25.6 & 19.9 & 26.1 & 19.9 & 0.0 & 18.2 \\
\hline 2 & 1.6 & 23.8 & 34.4 & 35.7 & 21.2 & 27.0 & 0.0 & 25.0 \\
\hline 3 & 11.3 & 36.3 & 43.2 & 45.7 & 50.2 & 41.0 & 4.0 & 39.9 \\
\hline 4 & 21.3 & 42.1 & 49.2 & 56.5 & 41.3 & 42.8 & 17.8 & 42.3 \\
\hline 5 & 25.4 & 46.3 & 66.9 & 71.7 & 54.0 & 54.2 & 9.7 & 53.1 \\
\hline 6 & 31.5 & 57.3 & 60.7 & 81.5 & 78.3 & 64.1 & 0.0 & 63.6 \\
\hline 7 & 65.9 & 60.0 & 78.4 & 67.8 & 71.9 & 68.9 & 100.0 & 69.0 \\
\hline 8 & 70.5 & 69.9 & 80.5 & 80.4 & 77.4 & 76.6 & 43.8 & 76.4 \\
\hline 9 & 65.9 & 75.7 & 83.3 & 84.2 & 80.6 & 81.0 & 74.9 & 80.9 \\
\hline 10 & 46.4 & 74.0 & 89.3 & 90.4 & 79.1 & 85.8 & 0.0 & 85.4 \\
\hline All Income Groups & 28.1 & 55.0 & 67.3 & 69.3 & 58.6 & 60.2 & 9.1 & 59.1 \\
\hline
\end{tabular}

Table 2. Percentage of people aged 20 or more participating in private pensions by age and employment status, 2004

\begin{tabular}{|c|c|c|c|c|c|c|c|c|}
\hline \multirow{2}{*}{$\begin{array}{l}\text { Employment status } \\
\text { employed: }\end{array}$} & $20-24$ & $25-34$ & $35-44$ & $45-54$ & $55-64$ & $\begin{array}{l}\text { All Working } \\
\text { age (20-64) }\end{array}$ & $65+$ & All ages \\
\hline & 28.1 & 55.0 & 67.3 & 69.3 & 58.6 & 60.2 & 9.1 & 59.1 \\
\hline part-time & 15.2 & 34.9 & 45.3 & 50.5 & 33.3 & 40.6 & 4.4 & 38.4 \\
\hline full-time & 29.6 & 58.7 & 73.8 & 74.4 & 70.0 & 65.5 & 17.6 & 65.0 \\
\hline
\end{tabular}

\begin{tabular}{lcccccccc}
\hline \multicolumn{8}{c}{ Table 3. Percentage of people aged 20 } & or more participating in private pensions by age and gender, 2004 \\
\hline & $20-24$ & $25-34$ & $35-44$ & $45-54$ & $55-64$ & $\begin{array}{c}\text { All working } \\
\text { age (20-65) }\end{array}$ & $65+$ & All ages \\
\cline { 2 - 9 } & 29.5 & 54.5 & 72.9 & 73.3 & 64.6 & 63.5 & 5.9 & 61.9 \\
male & 26.4 & 55.6 & 61.6 & 65.1 & 51.1 & 56.6 & 15.1 & 55.9 \\
female & 28.1 & 55.0 & 67.3 & 69.3 & 58.6 & 60.2 & 9.1 & 59.1 \\
Total & & & & & & &
\end{tabular}

Note: Secretariat calculation from the BHPS. 


\section{Occupational pensions}

Table 1. Percentage of workers participating in employer pension plan by age and income level, 2004

\begin{tabular}{lcccccccc}
\hline & \multicolumn{8}{c}{ All Earners } \\
Income range (Deciles) & $20-24$ & $25-34$ & $35-44$ & $45-54$ & $55-64$ & $\begin{array}{c}\text { All Working } \\
\text { age (20-64) }\end{array}$ & $65+\quad$ All ages \\
\cline { 2 - 9 } 1 & 5.5 & 2.0 & 15.6 & 11.8 & 5.7 & 8.8 & 0.0 & 8.0 \\
2 & 1.6 & 15.4 & 24.0 & 24.6 & 11.0 & 17.8 & 0.0 & 16.5 \\
3 & 7.9 & 28.1 & 34.3 & 36.6 & 28.6 & 30.1 & 0.0 & 29.3 \\
4 & 18.5 & 33.5 & 34.9 & 37.4 & 29.9 & 31.2 & 17.8 & 30.9 \\
5 & 25.4 & 37.8 & 55.2 & 59.1 & 40.8 & 44.8 & 0.0 & 43.7 \\
6 & 29.2 & 45.3 & 48.7 & 59.1 & 55.1 & 49.0 & 0.0 & 48.6 \\
7 & 62.4 & 50.6 & 64.8 & 51.4 & 56.6 & 56.4 & 100.0 & 56.4 \\
8 & 62.2 & 63.2 & 65.3 & 65.1 & 63.8 & 64.3 & 43.8 & 64.2 \\
9 & 65.9 & 64.0 & 74.9 & 64.8 & 69.3 & 68.5 & 53.5 & 68.4 \\
10 & 46.4 & 65.8 & 70.0 & 76.9 & 64.3 & 70.7 & 0.0 & 70.4 \\
All Income Groups & 26.0 & 45.8 & 54.3 & 54.1 & 42.8 & 48.0 & 6.3 & 47.1 \\
\hline
\end{tabular}

Table 2. Percentage of people aged 20 or more participating in employer pension plan by age and employment status, 2004

\begin{tabular}{|c|c|c|c|c|c|c|c|c|}
\hline \multirow{2}{*}{$\begin{array}{l}\text { Employment status } \\
\text { employed: }\end{array}$} & $20-24$ & 25-34 & $35-44$ & $45-54$ & $55-64$ & $\begin{array}{l}\text { All Working } \\
\text { age }(20-64)\end{array}$ & $65+$ & All ages \\
\hline & 26.0 & 45.8 & 54.3 & 54.1 & 42.8 & 48.0 & 6.3 & 47.1 \\
\hline part-time & 15.2 & 30.6 & 38.3 & 42.2 & 22.5 & 33.2 & 3.7 & 31.3 \\
\hline full-time & 27.3 & 48.6 & 59.0 & 57.4 & 52.0 & 52.0 & 11.1 & 51.6 \\
\hline
\end{tabular}

\begin{tabular}{|c|c|c|c|c|c|c|c|c|}
\hline sex & $20-24$ & $25-34$ & $35-44$ & $45-54$ & $55-64$ & $\begin{array}{l}\text { All working } \\
\text { age }(20-65)\end{array}$ & $65+$ & All ages \\
\hline male & 26.3 & 41.3 & 54.7 & 52.7 & 41.6 & 46.4 & 4.1 & 45.3 \\
\hline female & 25.7 & 51.1 & 53.8 & 55.6 & 44.4 & 49.9 & 10.5 & 49.2 \\
\hline Total & 26.0 & 45.8 & 54.3 & 54.1 & 42.8 & 48.0 & 6.3 & 47.1 \\
\hline
\end{tabular}

Note: Secretariat calculation from the BHPS. 


\section{Personal plans}

Table 1. Percentage of people employed participating in personal private pension plan by age and income level, 2004

\begin{tabular}{|c|c|c|c|c|c|c|c|c|}
\hline \multirow[b]{2}{*}{ Income range (Deciles) } & \multicolumn{8}{|c|}{ All Earners } \\
\hline & $20-24$ & $25-34$ & $35-44$ & $45-54$ & $55-64$ & $\begin{array}{l}\text { All Working } \\
\text { age }(20-64)\end{array}$ & $65+$ & All ages \\
\hline 1 & 0.0 & 9.5 & 9.9 & 8.1 & 20.4 & 11.1 & 0.0 & 10.2 \\
\hline 2 & 0.0 & 9.5 & 12.1 & 14.1 & 10.3 & 10.6 & 0.0 & 9.8 \\
\hline 3 & 7.3 & 10.0 & 11.3 & 15.5 & 24.1 & 14.3 & 4.0 & 14.0 \\
\hline 4 & 2.8 & 10.4 & 16.1 & 27.6 & 13.8 & 14.6 & 17.8 & 14.7 \\
\hline 5 & 3.1 & 10.3 & 21.5 & 22.7 & 22.4 & 16.4 & 9.7 & 16.2 \\
\hline 6 & 2.3 & 15.2 & 17.9 & 32.0 & 30.7 & 20.8 & 0.0 & 20.6 \\
\hline 7 & 6.3 & 14.6 & 18.1 & 28.2 & 30.4 & 20.4 & 0.0 & 20.3 \\
\hline 8 & 16.2 & 15.6 & 25.6 & 24.4 & 26.5 & 22.3 & 43.8 & 22.4 \\
\hline 9 & 0.0 & 18.9 & 13.6 & 32.1 & 23.9 & 21.0 & 74.9 & 21.5 \\
\hline 10 & 0.0 & 19.3 & 32.0 & 29.9 & 34.2 & 29.6 & 0.0 & 29.5 \\
\hline All Income Groups & 3.8 & 14.1 & 19.6 & 25.3 & 24.1 & 19.1 & 8.2 & 18.9 \\
\hline
\end{tabular}

\begin{tabular}{|c|c|c|c|c|c|c|c|c|}
\hline \multirow{2}{*}{$\begin{array}{l}\text { Employment status } \\
\text { employed: }\end{array}$} & $20-24$ & $25-34$ & $35-44$ & $45-54$ & $55-64$ & $\begin{array}{l}\text { All Working } \\
\text { age (20-64) }\end{array}$ & $65+$ & All ages \\
\hline & 3.8 & 14.1 & 19.6 & 25.3 & 24.1 & 19.1 & 8.2 & 18.9 \\
\hline part-time & 0.0 & 7.1 & 9.4 & 15.2 & 13.2 & 10.9 & 3.1 & 10.4 \\
\hline full-time & 4.3 & 15.4 & 22.6 & 28.0 & 29.0 & 21.3 & 17.6 & 21.3 \\
\hline
\end{tabular}

\begin{tabular}{|c|c|c|c|c|c|c|c|c|}
\hline & $20-24$ & $25-34$ & $35-44$ & $45-54$ & $55-64$ & $\begin{array}{l}\text { All working } \\
\text { age (20-65) }\end{array}$ & $65+$ & All ages \\
\hline male & 6.0 & 18.6 & 26.5 & 32.6 & 33.1 & 25.5 & 5.9 & 24.9 \\
\hline female & 1.2 & 8.8 & 12.5 & 17.5 & 12.8 & 12.0 & 12.5 & 12.1 \\
\hline Total & 3.8 & 14.1 & 19.6 & 25.3 & 24.1 & 19.1 & 8.2 & 18.9 \\
\hline
\end{tabular}

Note: Secretariat calculation from the BHPS. 


\section{Results for Norway using the Luxembourg Wealth Study Data Set, 2002}

Table 1. Percentage of workers participating in private pension by age and income level, 2002

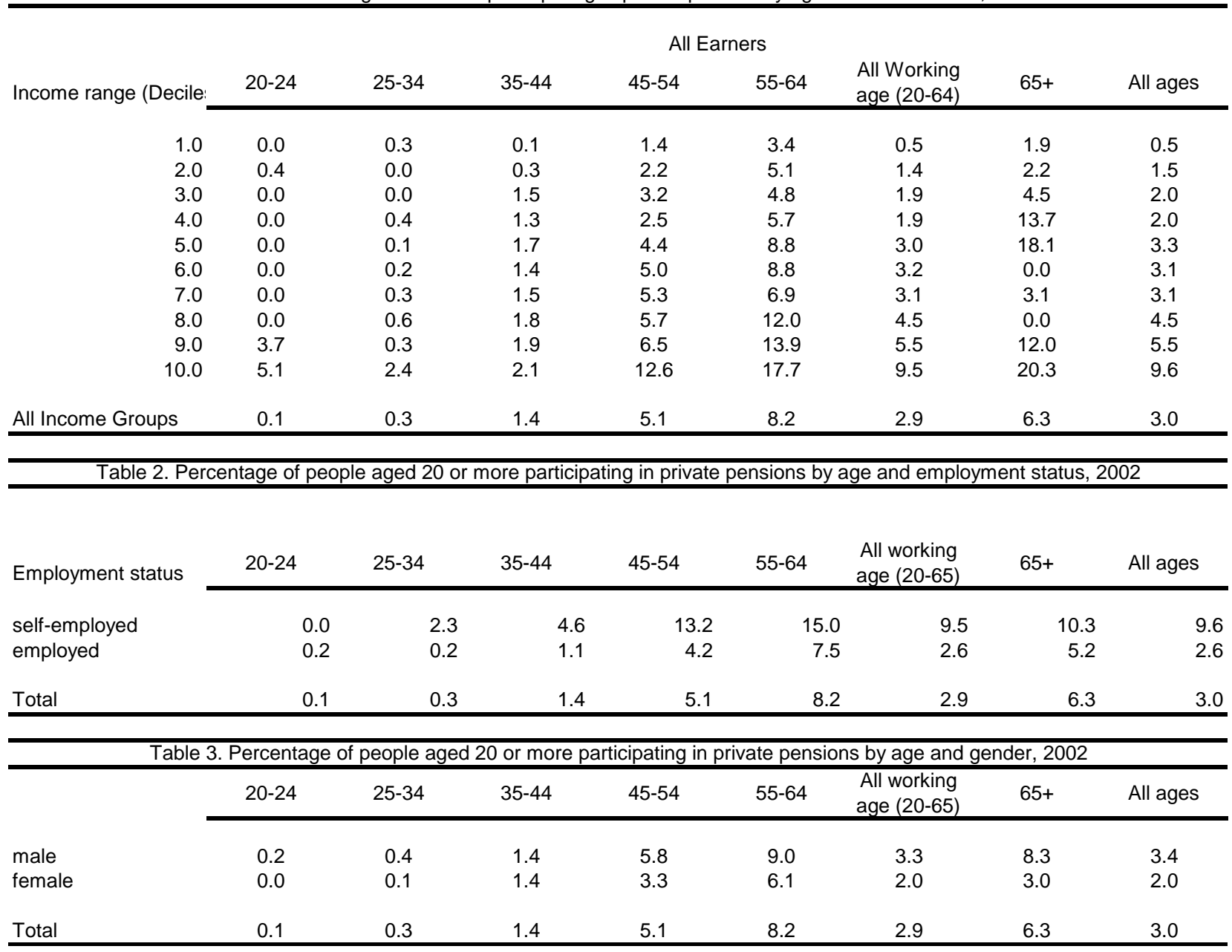




\section{Results for the United States from the Panel Survey of Income Dynamics (PSID), 2005}

\section{Total}

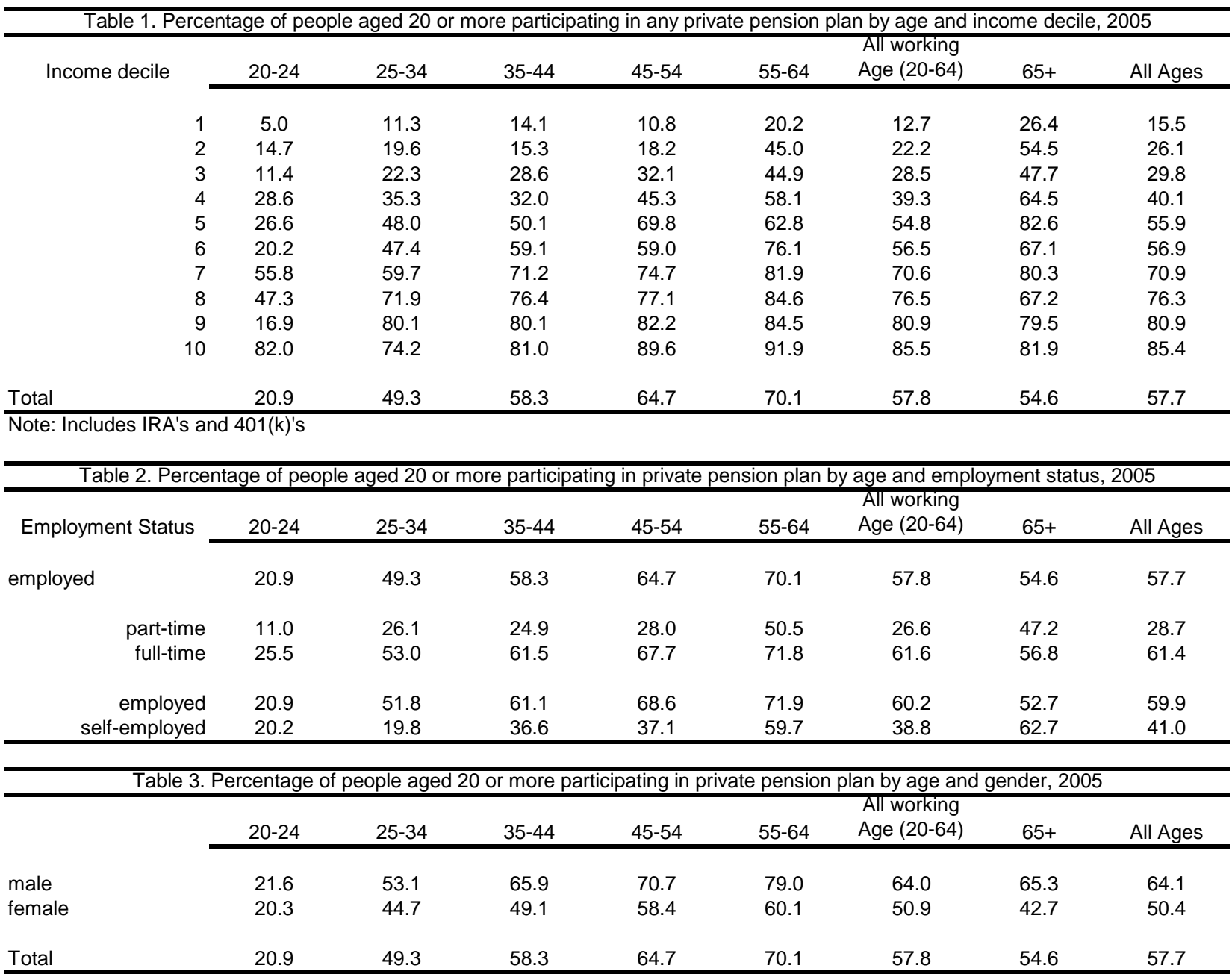




\section{Occupational pension plans}

\begin{tabular}{|c|c|c|c|c|c|c|c|c|}
\hline Income decile & $20-24$ & $25-34$ & $35-44$ & $45-54$ & $55-64$ & $\begin{array}{l}\text { All working } \\
\text { Age }(20-64)\end{array}$ & $65+$ & All Ages \\
\hline 1 & 2.7 & 7.9 & 11.2 & 4.7 & 2.9 & 6.5 & 1.9 & 5.6 \\
\hline 2 & 11.1 & 11.7 & 10.9 & 14.6 & 23.5 & 14.2 & 21.9 & 15.1 \\
\hline 3 & 11.0 & 17.0 & 23.8 & 22.6 & 26.7 & 20.7 & 29.1 & 21.3 \\
\hline 4 & 20.8 & 33.9 & 27.3 & 40.6 & 36.6 & 33.0 & 34.0 & 33.1 \\
\hline 5 & 24.6 & 45.7 & 44.7 & 60.7 & 42.4 & 47.3 & 47.6 & 47.3 \\
\hline 6 & 20.2 & 37.1 & 50.2 & 52.8 & 58.4 & 47.1 & 13.8 & 45.7 \\
\hline 7 & 55.8 & 52.4 & 62.0 & 65.4 & 67.3 & 61.2 & 28.3 & 60.1 \\
\hline 8 & 45.3 & 60.0 & 62.3 & 67.1 & 76.0 & 65.3 & 46.3 & 64.8 \\
\hline 9 & 16.9 & 68.5 & 68.6 & 70.8 & 69.7 & 69.0 & 39.8 & 68.3 \\
\hline 10 & 52.0 & 58.8 & 57.8 & 68.6 & 71.7 & 64.5 & 37.7 & 63.9 \\
\hline Total & 17.7 & 41.7 & 47.5 & 54.2 & 53.0 & 47.2 & 22.8 & 46.0 \\
\hline \multirow[t]{2}{*}{ Employment Status } & $20-24$ & $25-34$ & $35-44$ & $45-54$ & $55-64$ & $\begin{array}{l}\text { All working } \\
\text { Age }(20-64)\end{array}$ & $65+$ & All Ages \\
\hline & 17.7 & 41.7 & 47.5 & 54.2 & 53.0 & 47.2 & 22.8 & 46.0 \\
\hline \multirow{2}{*}{$\begin{array}{r}\text { part-time } \\
\text { full-time }\end{array}$} & 7.8 & 15.0 & 15.1 & 12.1 & 7.0 & 12.2 & 8.3 & 11.8 \\
\hline & 22.2 & 45.9 & 50.6 & 57.6 & 57.0 & 51.4 & 27.0 & 50.3 \\
\hline \multirow{2}{*}{$\begin{array}{r}\text { employed } \\
\text { self-employed }\end{array}$} & 18.2 & 45.1 & 52.6 & 60.1 & 59.0 & 51.8 & 28.2 & 50.7 \\
\hline & 7.1 & 3.4 & 10.3 & 13.2 & 18.8 & 11.9 & 3.0 & 11.1 \\
\hline \multicolumn{9}{|c|}{ Table 3. Percentage of people aged 20 or more participating in employer pension plan by age and gender, 2005} \\
\hline Employment Status & $20-24$ & $25-34$ & $35-44$ & $45-54$ & $55-64$ & Age (20-64) & $65+$ & All Ages \\
\hline male & 20.1 & 41.8 & 49.1 & 54.2 & 52.7 & 47.8 & 16.2 & 46.2 \\
\hline female & 15.4 & 41.5 & 45.6 & 54.1 & 53.3 & 46.6 & 30.1 & 45.7 \\
\hline Total & 17.7 & 41.7 & 47.5 & 54.2 & 53.0 & 47.2 & 22.8 & 46.0 \\
\hline
\end{tabular}




\section{Occupation DB pension plans}

\begin{tabular}{|c|c|c|c|c|c|c|c|c|}
\hline Income decile & $20-24$ & $25-34$ & $35-44$ & $45-54$ & $55-64$ & $\begin{array}{l}\text { All working } \\
\text { Age }(20-64)\end{array}$ & $65+$ & All Ages \\
\hline 1 & 0.2 & 0.9 & 9.1 & 0.4 & 2.9 & 3.2 & 1.9 & 2.9 \\
\hline 2 & 1.4 & 5.2 & 7.7 & 2.8 & 10.3 & 5.5 & 13.9 & 6.5 \\
\hline 3 & 6.5 & 6.2 & 6.4 & 9.9 & 10.1 & 7.8 & 20.3 & 8.6 \\
\hline 4 & 9.9 & 17.0 & 18.1 & 18.4 & 17.4 & 17.0 & 17.2 & 17.0 \\
\hline 5 & 11.9 & 19.9 & 22.5 & 26.2 & 27.5 & 22.6 & 17.2 & 22.4 \\
\hline 6 & 11.7 & 16.1 & 26.9 & 30.5 & 24.7 & 23.9 & 13.8 & 23.4 \\
\hline 7 & 32.4 & 32.0 & 36.7 & 41.5 & 40.9 & 37.5 & 0.0 & 36.3 \\
\hline 8 & 9.8 & 38.7 & 35.8 & 43.1 & 50.9 & 40.8 & 36.4 & 40.7 \\
\hline 9 & 15.9 & 42.3 & 42.5 & 45.7 & 52.1 & 44.8 & 9.8 & 44.0 \\
\hline 10 & 52.0 & 26.4 & 32.3 & 41.8 & 43.1 & 37.3 & 22.0 & 36.9 \\
\hline Total & 8.1 & 22.4 & 27.2 & 31.3 & 32.0 & 27.0 & 12.3 & 26.2 \\
\hline \multirow{3}{*}{ Employment Status } & & & & & & All working & & \\
\hline & $20-24$ & $25-34$ & $35-44$ & $45-54$ & $55-64$ & Age (20-64) & $65+$ & All Ages \\
\hline & 8.1 & 22.4 & 27.2 & 31.3 & 32.0 & 27.0 & 12.3 & 26.2 \\
\hline part-time & 2.2 & 6.7 & 4.9 & 6.7 & 3.7 & 5.2 & 5.2 & 5.2 \\
\hline full-time & 10.8 & 24.9 & 29.3 & 33.3 & 34.5 & 29.6 & 14.4 & 28.9 \\
\hline employed & 8.5 & 24.2 & 30.5 & 35.3 & 36.6 & 30.0 & 15.6 & 29.3 \\
\hline self-employed & 0.0 & 1.5 & 1.9 & 3.5 & 6.9 & 3.4 & 0.0 & 3.1 \\
\hline \multicolumn{9}{|c|}{$\begin{array}{c}\text { Table 3. Percentage of people aged } 20 \text { or more participating in DB- employer pension plan by age and gender, } 2005 \\
\text { All working }\end{array}$} \\
\hline & $20-24$ & $25-34$ & $35-44$ & $45-54$ & $55-64$ & Age (20-64) & $65+$ & All Ages \\
\hline male & 20.14 & 41.78 & 49.08 & 54.2 & 52.65 & 26.08 & 16.16 & 25.06 \\
\hline female & 15.44 & 41.52 & 45.55 & 54.13 & 53.32 & 27.91 & 30.09 & 27.43 \\
\hline Total & 17.71 & 41.66 & 47.47 & 54.17 & 52.96 & 26.95 & 22.78 & 26.18 \\
\hline
\end{tabular}




\section{Occupational DC pension plans}

\begin{tabular}{|c|c|c|c|c|c|c|c|c|}
\hline Income Decile & $20-24$ & $25-34$ & $35-44$ & $45-54$ & $55-64$ & $\begin{array}{l}\text { All working } \\
\text { Age }(20-64)\end{array}$ & $65+$ & All Ages \\
\hline 1 & 2.4 & 3.7 & 2.5 & 2.5 & 0.0 & 2.3 & 1.9 & 2.2 \\
\hline 2 & 3.0 & 6.3 & 2.8 & 7.9 & 11.8 & 6.4 & 11.0 & 7.0 \\
\hline 3 & 6.7 & 7.7 & 12.1 & 7.1 & 11.5 & 9.1 & 5.9 & 8.8 \\
\hline 4 & 12.1 & 19.1 & 10.8 & 18.3 & 19.2 & 16.0 & 15.4 & 16.0 \\
\hline 5 & 9.0 & 23.4 & 14.0 & 32.2 & 16.4 & 21.4 & 23.0 & 21.4 \\
\hline 6 & 12.7 & 16.2 & 29.2 & 27.8 & 26.1 & 24.1 & 0.0 & 23.1 \\
\hline 7 & 13.5 & 22.8 & 27.5 & 27.5 & 37.3 & 27.6 & 28.3 & 27.6 \\
\hline 8 & 8.2 & 20.9 & 31.9 & 26.1 & 37.4 & 28.2 & 14.8 & 27.9 \\
\hline 9 & 0.0 & 34.0 & 27.4 & 30.3 & 28.2 & 29.6 & 14.3 & 29.2 \\
\hline 10 & 0.0 & 39.2 & 30.0 & 34.3 & 41.3 & 34.7 & 24.8 & 34.5 \\
\hline Total & 7.3 & 19.9 & 21.7 & 24.7 & 26.1 & 22.0 & 10.6 & 21.4 \\
\hline \multirow[b]{2}{*}{ Employment Status } & & & & & & All working & & \\
\hline & $20-24$ & $25-34$ & $35-44$ & $45-54$ & $55-64$ & Age (20-64) & $65+$ & All Ages \\
\hline employed & 7.3 & 19.9 & 21.7 & 24.7 & 26.1 & 22.0 & 10.6 & 21.4 \\
\hline part-time & 3.8 & 3.4 & 7.1 & 4.1 & 2.8 & 4.4 & 5.4 & 4.5 \\
\hline full-time & 8.9 & 22.5 & 23.2 & 26.3 & 28.2 & 24.2 & 12.1 & 23.6 \\
\hline employed & 7.7 & 21.4 & 23.9 & 27.0 & 28.9 & 24.0 & 12.7 & 23.4 \\
\hline self-employed & 0.0 & 3.4 & 6.3 & 7.6 & 11.1 & 7.2 & 3.0 & 6.8 \\
\hline \multicolumn{9}{|c|}{$\frac{\text { Table 3. Percentage of people aged } 20 \text { or more participating in DC- employer pension plan by age and gender, } 2005}{\text { All working }}$} \\
\hline Employment Status & $20-24$ & $25-34$ & $35-44$ & $45-54$ & $55-64$ & Age $(20-64)$ & $65+$ & All Ages \\
\hline male & 6.4 & 21.7 & 25.1 & 27.5 & 27.3 & 24.3 & 8.5 & 23.5 \\
\hline female & 8.2 & 17.8 & 17.7 & 21.7 & 24.9 & 19.5 & 12.9 & 19.1 \\
\hline Total & 7.3 & 19.9 & 21.7 & 24.7 & 26.1 & 22.0 & 10.6 & 21.4 \\
\hline
\end{tabular}


Households with IRAs

\begin{tabular}{|c|c|c|c|c|c|c|c|c|}
\hline Income decile & $20-24$ & $25-34$ & $35-44$ & $45-54$ & $55-64$ & $\begin{array}{l}\text { All working } \\
\text { Age }(20-64)\end{array}$ & $65+$ & All Ages \\
\hline 1 & 2.9 & 6.2 & 13.5 & 11.7 & 35.9 & 13.7 & 31.9 & 18.5 \\
\hline 2 & 4.2 & 11.4 & 8.7 & 11.3 & 44.5 & 14.8 & 63.5 & 21.5 \\
\hline 3 & 0.5 & 10.7 & 7.4 & 18.6 & 34.6 & 13.8 & 42.6 & 15.9 \\
\hline 4 & 9.0 & 6.0 & 12.8 & 23.1 & 37.6 & 16.5 & 51.0 & 18.1 \\
\hline 5 & 4.6 & 7.5 & 17.9 & 23.6 & 42.2 & 18.3 & 58.9 & 20.2 \\
\hline 6 & 13.4 & 19.2 & 21.6 & 24.9 & 61.9 & 26.8 & 61.8 & 28.6 \\
\hline 7 & 0.0 & 27.8 & 27.1 & 41.3 & 56.0 & 35.5 & 79.7 & 37.0 \\
\hline 8 & 11.2 & 33.9 & 36.3 & 44.9 & 44.6 & 38.9 & 23.4 & 38.5 \\
\hline 9 & 0.0 & 38.9 & 36.8 & 39.6 & 53.5 & 40.5 & 82.3 & 41.5 \\
\hline 10 & 82.0 & 54.1 & 64.5 & 71.2 & 70.6 & 67.2 & 76.4 & 67.5 \\
\hline Total & 6.1 & 22.9 & 32.2 & 40.1 & 51.9 & 33.6 & 52.1 & 34.7 \\
\hline & & & & & & All working & & \\
\hline Employment Status & $20-24$ & $25-34$ & $35-44$ & $45-54$ & $55-64$ & Age (20-64) & $65+$ & All Ages \\
\hline employed & 6.1 & 22.9 & 32.2 & 40.1 & 51.9 & 33.6 & 52.1 & 34.7 \\
\hline part-time & 3.6 & 18.8 & 18.4 & 34.2 & 67.0 & 23.6 & 51.0 & 26.6 \\
\hline full-time & 7.2 & 23.6 & 33.5 & 40.5 & 50.7 & 34.8 & 52.4 & 35.7 \\
\hline employed & 5.7 & 22.9 & 30.0 & 39.5 & 48.5 & 31.8 & 46.8 & 32.6 \\
\hline self-employed & 13.6 & 22.1 & 48.3 & 42.7 & 69.0 & 46.2 & 69.7 & 48.7 \\
\hline male & 4.4 & 24.7 & 35.6 & 42.7 & 56.3 & 36.8 & 57.3 & 37.8 \\
\hline female & 8.2 & 17.5 & 20.8 & 32.2 & 39.6 & 24.6 & 41.9 & 25.9 \\
\hline Total & 6.1 & 22.9 & 32.2 & 40.1 & 51.9 & 33.6 & 52.1 & 34.7 \\
\hline
\end{tabular}




\section{Results for Ireland}

\section{Total}

Table1. Percentage of workers participating by age and income level, 2005Q4

\begin{tabular}{|c|c|c|c|c|c|c|c|c|}
\hline \multirow[b]{2}{*}{ Income range $^{1}$} & \multicolumn{8}{|c|}{ All Earners } \\
\hline & $20-24$ & 25-34 & $35-44$ & $45-54$ & $55-69$ & $\begin{array}{c}\text { All working } \\
\text { age }\end{array}$ & $65+$ & all ages \\
\hline range 1 & & & & & & & & \\
\hline range 2 & & & & & & & & \\
\hline range 3 & & & & & & & & \\
\hline range 4 & & & & & & & & \\
\hline range 5 & & & & & & & & \\
\hline range 6 & & & & & & & & \\
\hline range 7 & & & & & & & & \\
\hline range 8 & & & & & & & & \\
\hline range 9 & & & & & & & & \\
\hline range 10 & & & & & & & & \\
\hline All Income Groups & 27.5 & 53.0 & 65.1 & 64.0 & 53.3 & & & 55.0 \\
\hline
\end{tabular}

Note: each income range contains $1 / 10$ of the relevant population.

Source: Irish Central Statistics Office, Quarterly National Household Survey, 2005Q4

\section{Occupational pensions}

Table1. Percentage of workers participating by age and income level, 2005Q4

\begin{tabular}{l} 
Income range ${ }^{1}$ \\
\cline { 2 - 4 } \\
\cline { 2 - 4 } range 1 \\
range 2 \\
range 3 \\
range 4 \\
range 5 \\
range 6 \\
range 7 \\
range 8 \\
range 9 \\
range 10 \\
All Income Groups
\end{tabular}




\section{Personal plans}

Table1. Percentage of workers participating by age and income level, 2005Q4

\begin{tabular}{|c|c|c|c|c|c|c|c|c|}
\hline \multirow[b]{2}{*}{ Income range $^{1}$} & \multicolumn{8}{|c|}{ All Earners } \\
\hline & $20-24$ & $25-34$ & $35-44$ & $45-54$ & $55-64$ & $\begin{array}{c}\text { All working } \\
\text { age }\end{array}$ & $65+$ & all ages \\
\hline \multicolumn{9}{|l|}{ range 1} \\
\hline \multicolumn{9}{|l|}{ range 2} \\
\hline \multicolumn{9}{|l|}{ range 3} \\
\hline \multicolumn{9}{|l|}{ range 4} \\
\hline \multicolumn{9}{|l|}{ range 5} \\
\hline \multicolumn{9}{|l|}{ range 6} \\
\hline \multicolumn{9}{|l|}{ range 7} \\
\hline \multicolumn{9}{|l|}{ range 8} \\
\hline \multicolumn{9}{|l|}{ range 9} \\
\hline \multicolumn{9}{|l|}{ range 10} \\
\hline All Income Groups & 3.1 & 10.2 & 19.7 & 19.0 & 22.1 & & & 14.9 \\
\hline
\end{tabular}

Note: each income range contains $1 / 10$ of the relevant population.

Source: Irish Central Statistics Office, Quarterly National Household Survey, 2005Q4 